\title{
Fiscal Capacity and Commercial Bank Lending Under COVID-19
}

\author{
Joshua Aizenman \\ University of Southern California \\ University Park Los Angeles \\ Yothin Jinjarak \\ Asian Development Bank \\ Mark M. Spiegel \\ Federal Reserve Bank of San Francisco \\ March 2023 \\ Working Paper 2022-04
}

https://www.frbsf.org/economic-research/publications/working-papers/2022/04/

\section{Suggested citation:}

Aizenman, Joshua, Yothin Jinjarak, Mark M. Spiegel. 2023 "Fiscal Capacity and Commercial Bank Lending Under COVID-19," Federal Reserve Bank of San Francisco Working Paper 2022-04. https://doi.org/10.24148/wp2022-04 This paper was previously circulated under the title "Fiscal Stimulus and Commercial Bank Lending Under COVID-19."

The views in this paper are solely the responsibility of the authors and should not be interpreted as reflecting the views of the Federal Reserve Bank of San Francisco or the Board of Governors of the Federal Reserve System. 


\title{
Fiscal Capacity and Commercial Bank Lending Under COVID-19
}

\author{
Joshua Aizenman \\ University of Southern California \\ University Park Los Angeles \\ Yothin Jinjarak \\ Asian Development Bank \\ Mark M. Spiegel \\ Federal Reserve Bank of San Francisco \\ March 2023 \\ Working Paper 2023-11
}

https://www.frbsf.org/economic-research/publications/working-papers/2023/11/

\section{Suggested citation:}

Aizenman, Joshua, Yothin Jinjarak, Mark M. Spiegel. 2023 "Fiscal Capacity and Commercial Bank Lending Under COVID-19," Federal Reserve Bank of San Francisco Working Paper 2023-11. https://doi.org/10.24148/wp2023-11

The views in this paper are solely the responsibility of the authors and should not be interpreted as reflecting the views of the Federal Reserve Bank of San Francisco or the Board of Governors of the Federal Reserve System. 


\title{
Fiscal capacity and commercial bank lending under COVID-19
}

\author{
Joshua Aizenman, Yothin Jinjarak, and Mark M. Spiegel ${ }^{1}$
}

March 2023

\begin{abstract}
We investigate the implications of government indebtedness for the efficacy of expansionary government spending in encouraging commercial bank lending growth during the COVID-19 pandemic. Our sample is a large cross-section of over 3000 banks from 71 countries. To address the likely endogeneity of government assistance, we instrument for extra-normal spending using disparities in pre-existing national political characteristics. Our results indicate that bank lending did respond to fiscal capacity, as higher public debt going into the crisis weakened the expansionary effects of higher spending on bank lending at economically and statistically significant levels. Moreover, this sensitivity was higher among weaker banks, suggesting sensitivity to the perceived implications of spending for government assistance going forward. We also found greater sensitivity in high-income economies and for small and medium-sized banks. Our results are robust to a variety of robustness tests, including perturbations in specification, sample, and estimation methodology.
\end{abstract}

JEL Classification: G21, E62, F34, H30

Keywords: fiscal capacity, COVID-19, bank lending

\footnotetext{
${ }^{1}$ Joshua Aizenman: Economics and SIR, University of Southern California, University Park Los Angeles, CA 900890043 and NBER aizenman@usc.edu; Yothin Jinjarak: ERCD, Asian Development Bank, Mandaluyong City 1550 Metro Manila, Philippines, yjinjarak@adb.org; Mark M. Spiegel: Economic Research, 101 Market Street, MS 1130, United States, San Francisco, California, 94105, mark.spiegel@sf.frb.org. We are grateful for insightful comments provided by an anonymous reviewer and the editor. Olivia Lofton provided excellent research assistance. Joshua Aizenman is grateful for the support provided by the Dockson Chair in Economics and International Relations, USC. The views in this paper are solely the responsibility of the authors and should not be interpreted as reflecting the views of the Federal Reserve Bank of San Francisco, the Board of Governors of the Federal Reserve System, the National Bureau of Economic Research, or the Asian Development Bank.
} 


\section{Introduction}

The COVID-19 pandemic raised the need for elevated government spending to fight the pandemic and to stabilize national economies. This resulted in sizable increases in fiscal outlays, and greater liquidly support of households, businesses, and banks. As noted by Gopinath (November 2020), "The considerable global fiscal support of close to $\$ 12$ trillion and the extensive rate cuts, liquidity injections, and asset purchases by central banks helped saved lives and livelihoods and prevented a financial catastrophe."

Notably, at the arrival of the pandemic many national government balance sheets were in challenging positions. As shown in Acharya et al. (2014), the global financial crisis and the euro area crisis which followed shortly afterwards deteriorated government fiscal positions in a 'doom loop' between banks and their sovereigns. As distressed financial sectors necessitated national government bailouts, the cost of those bailouts raised government sovereign risk and further weakened the financial sector by eroding the value of both government guarantees and bank bond holdings. ${ }^{2}$ For the pandemic, the initial findings provided a mixed picture on the impact of policy interventions adopted in different countries. As pointed out in a review of Berger et al. (2021), there is still a need for more evidence from the detailed bank-level data to understand how banks behave during the crisis, and how the dynamics vary with bank and country characteristics.

Bank profitability and activity has been shown to respond to expected levels of government support. Correa et al. (2014) demonstrate that changes in sovereign credit ratings impact on local bank equity returns. They conclude that the link between these exposures based on the credibility of explicit

\footnotetext{
${ }^{2}$ Acharya et al (2014) identify a positive correlation between post-bailout movements in sovereign CDS spreads and changes in bank CDS spreads, even after controlling for aggregate and bank-level characteristics.
} 
and implicit government guarantees. Similarly, Brandao-Marques et al. (2020) show that bank risktaking is responsive to perceived implicit and explicit government guarantees.

In this paper, we investigate the impact of national fiscal positions on the efficacy of expansionary fiscal policy to maintain bank lending. The lockdowns in economic activity necessitated by the crisis, as well as disruptions to financial markets during the COVID pandemic, raised concerns that firms would face difficulty maintaining access to credit. While governments pursued extraordinary fiscal expansions to forestall credit declines, the responsiveness of the financial sector may have been sensitive to the perceived capacity of governments to engage in such expansionary policies while maintaining the credibility of their commitments to assist problematic institutions in the event of distress, or even failure. As such, the impact of fiscal expansions on bank activity may vary systematically by national fiscal positions going into the crisis. The COVID-19 crisis provides a useful experience in which to examine the link between fiscal capacity and the impact of fiscal expansion on credit creation, due to the exogenous nature of the COVID crisis that triggered the ensuing fiscal response.

We address this question through a large cross-section of approximately 3000 banks from 71 countries. We condition for disparities in individual bank and country characteristics going into the crisis based on data for 2019Q4. Our banking data includes balance sheet and income statement information taken from the Fitch Global Banking database. Importantly, we also control for disparities in country characteristics, including both the severity of the crisis and the government debt position going into the pandemic. Public debt/GDP has been commonly used as an indicator of fiscal space (e.g. Ostry et al. (2010)), and in particular may provide information about the willingness or capacity of the government to provide assistance to the banking system in future periods of distress. ${ }^{3}$

\footnotetext{
${ }^{3}$ Ostry et al. (2010) estimates of fiscal space depend on the debt/GDP projected, and estimated debt limit, which depends on the country's historical track record of primary balance adjustment to rising debt. In this context, Mian et al. (2014) show that following a financial crisis, voters become more ideologically extreme and ruling coalition become weaker, raising the difficulty of resolving debt-
} 
Our specification also pays attention to endogeneity concerns, as it is quite possible that countries that experienced more severe COVID responded with both greater lockdowns - which adversely impacted on activity and bank lending--and more assistance spending to alleviate the adverse implications of those lockdowns. In response, we turn to instrumental variables estimation based on the existing national political environment. We use as instruments four political indicators, including indicators of political rights, government effectiveness, the existence of a Presidential system of government, and a measure of the durability of a nation's political regimes. Specification and measurement of these are discussed below, and diagnostic tests reject any weak instrument problem.

We find that while higher government spending was associated weakly with higher commercial bank lending under the pandemic, higher public debt going into the crisis weakened the expansionary effects of higher spending on bank lending at economically and statistically significant levels. Moreover, sensitivity analysis demonstrates that a sub-sample of weaker banks, proxied by higher bad loan shares, exhibited greater sensitivity than their stronger counterparts, although our standard errors are too large for this difference in sensitivity to be established with statistical significance. We also find that the negative relationship between growth in lending by banks and high spending and government debt levels was more pronounced in high-income economies and for the medium and smaller banks in our sample. ${ }^{4}$ Finally, after accounting for this heterogeneity in sensitivity to extra-normal fiscal expenditures, we find that bank lending growth is increasing in extra-normal fiscal spending, although not always at statistically significant levels. Our results are robust to a variety of sensitivity analyses, including perturbations in specification, sample, and estimation methodology.

overhangs and reducing the likelihood of future bailouts. Cukierman and Izhakian (2015) showed that increases in bailout uncertainty can raise both interest rates and defaults.

${ }^{4}$ While we do not directly consider cross-border funding, this result is in line with Cetorelli and Goldberg (2012), as smaller banks are less exposed to cross-border funding opportunities and may not benefit from the more elastic public backstopping provided in times of peril to 'too big to fail' institutions. 
A related study by Çolak and Öztekin (2021) examined the effect of the COVID-19 crisis on global bank lending patterns across countries, accounting for bank characteristics, health systems, regulatory and supervisory practices, bank market structure, credit and bond market development, and borrower heterogeneity. They found that COVID-19 shock was felt more severely by the banks located in countries other than those located in the U.S. We interpret our results as complementary to the literature and suggesting that bank lending responses to government spending under COVID-19 reflected the perceived implications of such spending for government assistance of the banking sector going forward, which was negatively related to the severity of a nation's fiscal challenges.

While our analysis addresses the implications of direct spending, governments also used emergency lending measures to address the crisis. For example, Honda et al. (2022) studied the determinants of firms' use of the business support programs provided by the Japanese government during the COVID-19 pandemic, finding that firms were more likely to have obtained subsidized loans the more their sales had fallen during the pandemic. Bighelli et al. (2023) investigate cross-country evidence for five EU countries, Croatia, Finland, Netherlands, Slovakia, and Slovenia. They find that the pandemic led to a significant short-term decline in aggregate productivity and the direct support to firms had only a limited positive effect on productivity developments. Anderson et al. (2021) analyze national credit-support programs implemented in the context of fiscal policy in France, Germany, Italy, Spain, and the UK. They conclude that national governments implemented credit-support programs to prevent the massive negative shock of the COVID-19 pandemic and related lockdowns from immediately leading to a crippling wave of corporate insolvencies, and do not appear to have been constrained by fiscal capacity. Unfortunately, due to data limitations for our large cross-country sample, we cannot control for these government credit policies. Their omission implies that our indicators of government assistance will be measured with error, which may lead to attenuation in our estimated coefficients for the impact of government assistance policies on bank lending and our interactive term representing the influence 
of government debt positions on the efficacy of government assistance. However, as long as these errors are not systematically related to the measure of government assistance in our analysis, our results should be unbiased. That seems likely, as in some countries government credit policies probably were used as substitutes for direct assistance, while in others they were introduced in conjunction with direct assistance.

The remainder of this paper is organized into 6 sections. Section 2 introduces the data set and examines some univariate correlations between the variables of interest in the study. Section 3 introduces our parametric specification and illustrates our identification strategy. Section 4 reviews our base specification results. Section 5 subjects those results to a battery of robustness tests. Lastly, Section 6 concludes.

\section{Data}

Our sample is a large cross-section of over 3,000 commercial banks. Our observations come from 71 countries, including 36 high-income, 16 upper-middle-income, and 17 lower-middle-income, and 2 low-income economies. ${ }^{5}$ To guard against difficulties associated with endogeneity, explanatory variables are collected prior to the onset of the pandemic, at dates indicated in more detail below.

Our bank data consists of balance sheet and income statement variables for individual banks, taken from the Fitch Global Banking database. ${ }^{6}$ Pre-pandemic data on bank characteristics are taken

\footnotetext{
${ }^{5}$ More detail on sources and definitions of data used can be found in Appendix Table A1. We exclude banks from the United States as those would comprise well over half of our sample. We generally use unconsolidated data, only relying on consolidated data if banks fail to report unconsolidated statistics.

${ }^{6}$ Fitch sources its data through financial statements "... directly through web crawlers, alerts, by direct request and data feed." See https://app.fitchconnect.com/support for more detail. We remove a number of categories of non-banks from the original Fitch data set, including branches, bond banks, securities brokers, other brokerages, credit card banks, leasing subsidiaries, and factoring subsidiaries. To ensure a homogeneous set of private commercial banks, we also remove institutions designated as government sponsored enterprises.
} 
from 2019Q4, and lending growth is calculated based on annual changes from 2019Q4 through 2020Q4 to avoid issues associated with seasonality.

Our large sample of banks allows us to examine disparities in the effects of government pandemic assistance on bank lending across several dimensions, such as size and deposit-reliance. Following Lopez and Spiegel (2021), we separate reporting banks into three groups based on asset size in 2019Q4, i.e., small banks with assets below $\$ 10$ billion, large banks with assets exceeding $\$ 100$ billion, and a middle category between them. Our base specification contains 3,297 banks, of which 2,422 are classified as small banks, 690 are medium-size banks, and 185 classified as large banks. Following Lopez, et al (2020), we designate a bank as high deposit if its deposits comprise $75 \%$ or more of total funding. Over $74 \%$ of banks in our base regression sample are designated as high deposit under that definition. ${ }^{7}$ Our dependent variable is growth in bank lending, GLOAN, between 2019Q4 and 2020Q4. In addition to country-specific indicators discussed below, we account for differences in individual bank characteristics going into the COVID period. Other research has demonstrated the importance of conditioning for disparities in bank characteristics in explaining bank behavior or performance during the pandemic. For example, Cornett et al. (2011) showed that financially constrained banks were more limited in their credit extension during the global financial crisis.

Our base specification includes five individual-level bank conditioning variables. As these variables are measured prior to the pandemic, we can consider them pre-determined. We include LGLOAN, the lagged growth in bank lending over the previous year to control for bank lending growth trends, $B A D L$, the ratio of problem loans to total assets, as an indicator of the quality of bank lending; $\mathrm{CASH}$, the ratio of bank cash holdings to earning assets, as an indicator of bank balance sheet liquidity;

\footnotetext{
${ }^{7}$ We also follow Lopez, et al (2000) in using the more common accounting method used in its home country when confronted with bank data reported under multiple accounting methods and in dropping banks that use unconventional accounting systems, defined as an accounting system used in less than $10 \%$ of reported data in a bank's home country.
} 
$E Q U I$, the ratio of bank equity to total assets, as an indicator of bank leverage; and DEPO, the ratio of bank deposits to total funding, as an indicator of bank reliance on conventional funding. We also examine some available alternative measures in our robustness tests below. These additional bank-level measures include SIZE, the total assets in billion US\$, as an indicator of the bank size; CAPR, the Tier 1 capital to risk-weighted assets, as a measure of capital adequacy; ${ }^{8}$ and $L E V R$, the leverage ratio measured as the capital divided by total assets, as a measure of bank's near-term financial health.

We draw on several macroeconomic controls for the analysis. To assess the fiscal spending during COVID-19, we use above-the-line fiscal spending in \% of GDP, SPND (COVID-19 Fiscal Spending) from Fiscal Monitor Database of Country Fiscal Measures in Response to the COVID-19 Pandemic. This variable sums the additional spending or foregone revenues, covering health and non-health sectors, excluding accelerated spending and deferred revenue. Countries' responses vary depending on countryspecific circumstances, including the impact of the pandemic and other shocks. Also, estimates are reported as preliminary, as governments are taking additional measures or finalizing the details of individual measures. Despite these limitations, SPND provides a measure of government discretionary measures that supplement existing automatic stabilizers, which tend to correlate with GDP growth and differ across countries in their breadth and scope.

Our fiscal indicators and other country-level controls are drawn from national authorities and international organizations via Thomson Reuters Eikon. We consider as a stock measure of government indebtedness $D E B T$, the public debt/GDP ratio. Our estimation also controls for GGDP, GDP Growth, and $P O P N$, the size of population. A variable of interest below is the interaction of our measure of public debt with the spending indicator, SPNDXDEBT.

To control for the severity of COVID-19, we use an estimate of excess deaths (per million

\footnotetext{
${ }^{8}$ Crosignani (2021) provides a model where the sovereign debt capacity depends on the capitalization of domestic banks. As the capacity of public debt may depend on the bank capitalization, we condition for it with $C A P R$ in identifying the association between public debt and bank-lending growth in the estimation.
} 
population), CV19, from the Economist's Global Excess Deaths model. This measure represents the number of excess deaths, from all causes, during the COVID-19 pandemic. We consider this measure preferable to official COVID-19 mortality statistics which have proven prone to misreporting. However, expected deaths are subject to uncertainty, and so statistics are reported with confidence bands. We use the midpoints of these excess death confidence bands as our estimates. ${ }^{9}$

Finally, as discussed above, we use measures of country political characteristics as instruments for the likely-endogenous intensity of the fiscal spending response. These include $P O L R$, the political rights, which is an index from Freedom House, re-scaled to $(0,1)$, where the higher value corresponds to the higher degree of political freedom; DURA, the regime durability, which is the number of years since the most recent regime change as of 2018 from the Quality of Government Basic Dataset; and GVEF, the government effectiveness, which is an index from International Country Risk Guide (2019), with the values from 0 to 1 where a higher value corresponds to higher government effectiveness; and PRES, the presidential system, equals to 1 if a country has the presidential system and 0 otherwise, from the Database of Political Institutions.

These political variables assist our first-stage estimation in determining the size of COVID-19 spending and the pre-pandemic public debt levels in the cross-country sample. There are a number of channels identified in the literature through which a country's political regime could influence its COVID19 spending response. First, it may affect the cost of a given response. Qi et al. (2010) find that high levels of political rights are negatively associated with spreads of corporate bonds issued in 39 countries. They suggest that political rights allow for greater freedom of the press, which in turn reduces bond risks.

Second, enhanced political rights may encourage a more aggressive fiscal response to the

\footnotetext{
${ }^{9}$ The modeling of excess deaths involves comparing all deaths recorded with those expected to occur, and therefore itself is subject to estimation errors. Reported statistics of excess deaths thus contain confidence intervals, which can be sizable for some countries.
} 
pandemic. Fortunato and Loftis (2018) demonstrate that short durations in parliamentary democracies increase public spending by driving a political budget cycle. Examining 15 European democracies over several decades, they find that governments increase spending as their expected duration declines.

Third, domestic politics may affect the efficiency of the government, which may influence the chosen aggressiveness and eventual implementation of the pandemic response. Heylen et al. (2013) assess the evolution of the ratio of public debt to GDP during 132 fiscal episodes in 21 OECD countries in 1981-2008. They find that a given consolidation program will be more effective in bringing down debt when it is adopted by a more efficient government apparatus, and more efficient governments adopt consolidation programs of better composition. For the pandemic period, the effects of government effectiveness should be at work even more prominently on the fiscal spending during the COVID-19 crisis, and the interactions of the public-debt levels with the fiscal spending during the COVID-19 crisis, both of which can be considered as endogenous regressors in the main estimation.

The country grouping is based on the latest classification of income and geographic regions from World Bank: HIC for high-income countries; UMC for upper-middle income; and LMIC for lower-middle and low-income countries. We also supplement the analysis with the IMF's classification to identify emerging market and middle-income economies not classified as advanced economies or low-income developing countries, and the list of Euro membership. The bank-level and country-level observations are combined using 2-digit and 3-digit country letter codes in the respective datasets.

The list of countries, their average bank lending growth in 2020, and the numbers of banks included are in Appendix Table A2. We winsorize all variables at a $1 \%$ level to mitigate the influence of outliers. Standard errors are clustered by country unless indicated otherwise. Table 1 reports the summary statistics for the dependent variable and our variables of interest, GLOAN, SPND, SPNDxDEBT, and DEBT. In 2020, the mean bank lending growth is $5.6 \%$. There is a large variation in lending, from $19.4 \%$ to $30.8 \%$, with a standard deviation of $8.1 \%$, driven partly by banks in the upper middle-income 
countries, banks with assets less than $\$ 100 \mathrm{~B}$, and banks with deposits/total funding lower than 0.75

(Appendix Table A3 provides the summary statistics for sub-samples).

Table 1. Summary Statistics.

\begin{tabular}{ccccc}
\hline & Mean & SD & Min & Max \\
\hline GLOAN & 5.691 & 8.115 & -19.459 & 30.879 \\
SPND & 10.238 & 5.408 & 0.654 & 19.27 \\
SPNDxDEBT & 10.284 & 11.686 & 0.349 & 39.381 \\
DEBT & .836 & .627 & 0.138 & 2.354 \\
\hline
\end{tabular}

Note: Summary statistics for variables of interest in base specification sample. See text for variable definitions.

There is also a lot of variability in fiscal support in our sample. The size of above-the-line spending since COVID-19 has a mean of $10.2 \%$ of GDP. Some countries have spent close to a fifth of GDP, while others less than a percentage point, with a standard deviation of $5.4 \%$ of GDP. Given the public debt/GDP average of 0.8 with a standard deviation of 0.6 , the wide variation in scope and size of COVID-19 fiscal spending interacting with the public debt should prove useful in identifying the effects of fiscal challenges on bank lending growth.

Univariate patterns consistent with those in our parametric results below appear in our raw data. Figure 1 plots bank lending growth (\%) against COVID-19 fiscal spending/GDP (\%) for the countries included in our base sample, with circle sizes representing the number of banks per country. ${ }^{10}$ Note that the two large circles on the far right denote banks from Germany (the largest bubble) and banks from Japan (the second largest circle). We also show a fitted line based on the univariate relationship between the two variables, again based on individual bank observations. The sample correlation

\footnotetext{
${ }^{10}$ As our sample only includes private commercial bank lending, actual lending growth may be smaller or larger depending on the relative size of government bank lending growth. For some countries, lending by government financial institutions during this period was substantial. For example, see the case of Japan in Honda, et al. (2022).
} 
between the bank lending growth and the COVID-19 fiscal spending is 0.24 . The patterns suggest that government pandemic spending encourages lending growth by banks, with our point estimate (a bivariate estimation coefficient of 0.17 with a standard error of 0.01 ) indicating that a one standard deviation increase in above-normal fiscal spending ( $5.21 \%$ of GDP) is predicted to be associated with a $0.88=(5.21 * 0.17)$ percentage point increase bank lending growth .

Figure 1. Bank Lending Growth (\%) and COVID-19 Fiscal Spending/GDP (\%).

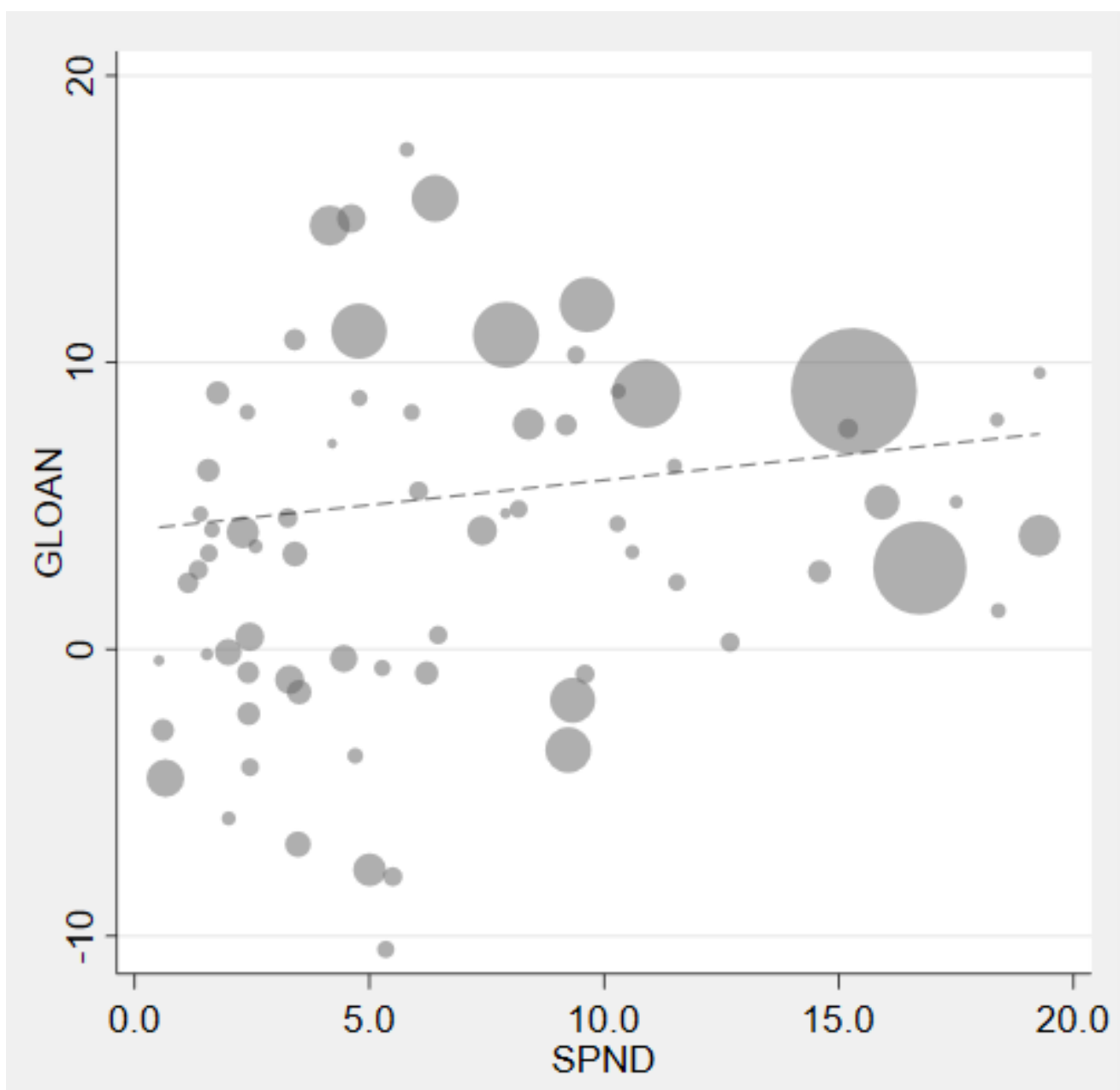

Note: Authors' calculation on bank loans from Fitch Solutions and above-the-line fiscal spending from IMF COVID-19 Tracker. Bubble's size and the fitted line are weighted by the frequency of observations at the level of 2020 abovethe-line spending/GDP. 
Figure 2 similarly displays the univariate relationship between bank lending growth (\%) and public debt/GDP. Our fitted line suggests that high government debt positions are a drag on lending growth during the pandemic, with our point estimate (a bivariate estimation coefficient of -1.12 , with a standard error of 0.15 ) indicating that a one standard deviation increase in the debt/GDP position (0.38)

Figure 2. Bank Lending Growth (\%) and Public Debt/GDP.

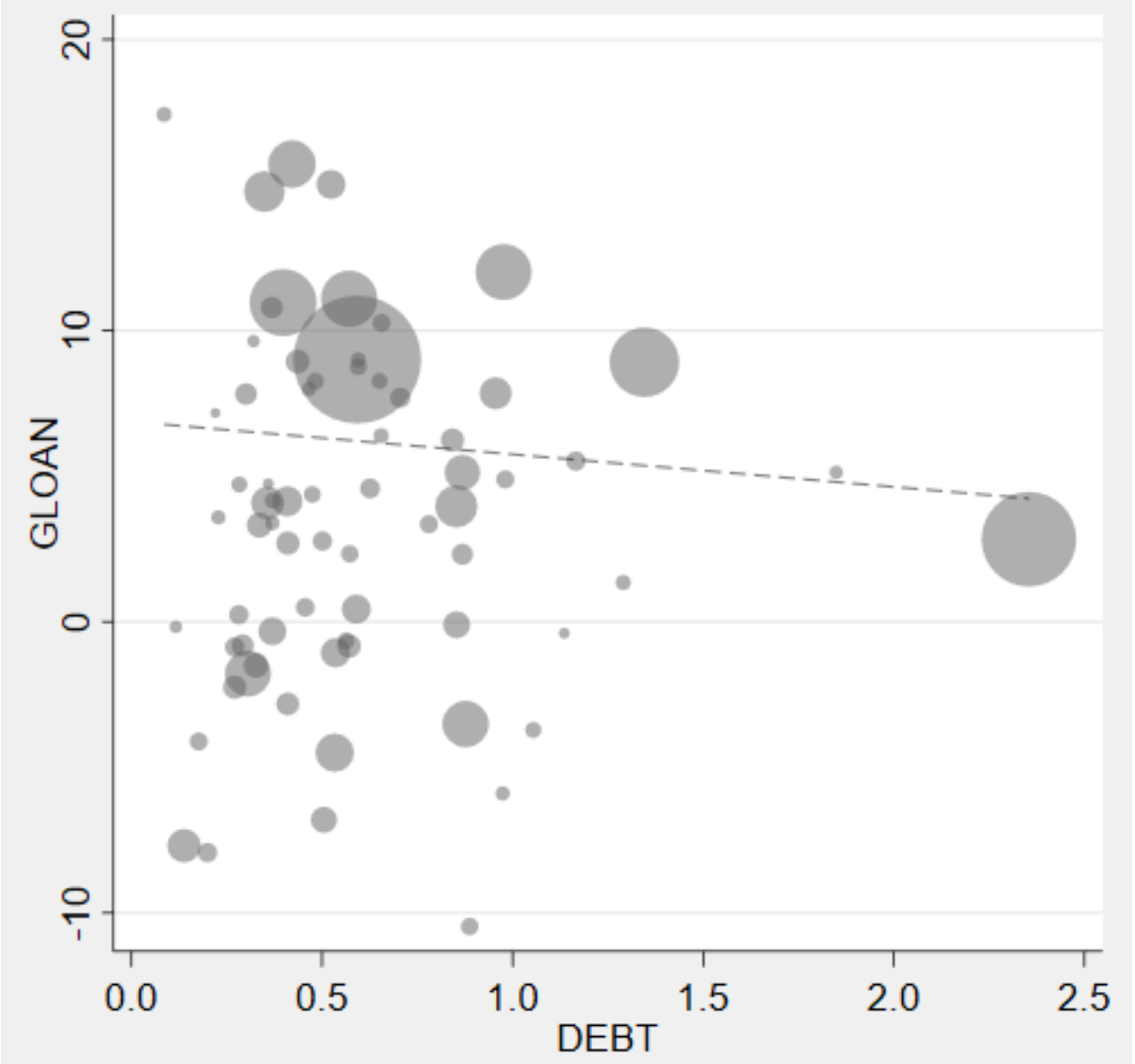

Note: Authors' calculation on bank loans from Fitch Solutions and national statistics on public debt to GDP. Circle sizes and the fitted line are weighted by the frequency of observations at the level of 2019 public debt/GDP.

is predicted to be associated with a $-0.42=(-1.12 * 0.38)$ percent decline in bank lending on average under the pandemic. However, it can also be seen that Japanese banks are influential in our sample, due 
to the high debt/GDP ratio prevailing in Japan relative to other countries during the pandemic. We examine this below.

Figure 3. Bank Lending Growth (\%) and the Interaction of COVID-19 Fiscal Spending/GDP (\%) and Public Debt/GDP. Lower bank lending growth with larger COVID-19 fiscal spending and public debt.

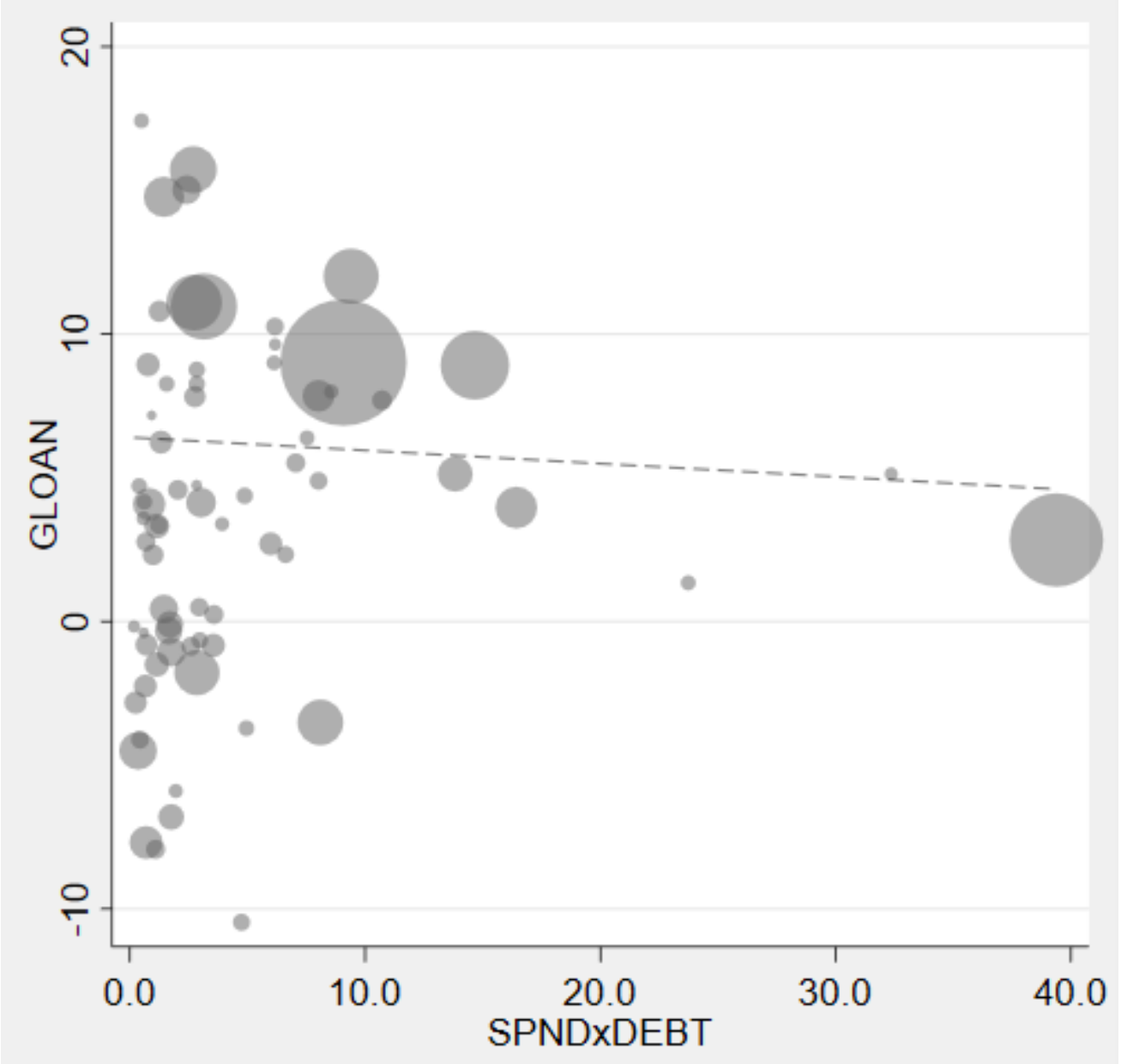

Note: Authors' calculation on bank loans from Fitch Solutions, above-the-line fiscal spending from IMF COVID-19 Tracker, and national statistics on public debt to GDP. Bubble's size and the fitted line are weighted by the frequency of observations at the value on horizontal axis (the product of above-the-line spending/GDP and public debt/GDP). 
Figure 3 then shows the relationship between bank lending growth (\%) and the interaction of COVID-19 fiscal spending/GDP (\%) and public debt/GDP. Larger levels of both COVID-19 fiscal spending and public debt are shown to be associated with lower bank lending growth during the pandemic, holding all else equal. Our point estimate for the fitted line (a bivariate-regression coefficient of -0.045 , with a standard error of 0.008 ) predicts that a one standard deviation increase in the interactive term (6.85) is associated with a $-0.31=(-0.045 * 6.85)$ percent decline in bank lending growth. Again, however, banks from Japan, shown on the large far-right bubble, appear to influence the overall pattern of the relationship.

Overall, our raw data suggests that above-normal fiscal spending during the pandemic is associated with bank lending growth, while high debt levels going into the pandemic were associated with lower lending growth, holding all else equal. In addition, we find a negative univariate relationship between lending growth and the interaction between above-normal fiscal spending and the sovereign debt burden going into the pandemic. In the next section, we move to test these relationships parametrically to examine their robustness to conditioning for disparities in bank and country characteristics.

\section{Methodology}

\subsection{Identification}

Our primary interest is in the impact of SPND, government spending above normal under the COVID-19 pandemic as a share of GDP, on bank lending growth, both on its own and interacted with the government's debt position as a share of GDP going into the pandemic, DEBT. As discussed in the previous section, we avoid endogeneity issues in the debt variable by using values as of end-2019. However, we are concerned about the potential for endogeneity in our spending variable, as it is quite possible that countries that experienced more severe incidence of COVID responded with greater 
lockdowns and more assistance spending to alleviate the adverse implications of those lockdowns. As our interactive term SPNDxDEBT also includes the likely-endogenous variable SPND, we treat it as endogenous as well and require at least two instruments.

In response, we turn to instrumental variables estimation. We consider it quite likely that all else equal, the political environment will influence the amount of government assistance spending undertaken. We therefore use the four political variables discussed above as instruments. A priori, we would expect that enhanced political rights, POLR, or government effectiveness, GVEF, would be associated with higher levels of government spending, as both would be associated with more intense responses to the pandemic, holding all else equal. We are more agnostic about the expected signs for PRES, the existence of a Presidential system of government, and DURA, a measure of the durability of a nation's political regimes.

Results for the first-stage regressions of our two-stage least squares specification with standard errors clustered by country are shown in Appendix Table A4. We indeed obtain statistically significant positive coefficient estimates on the GVEF variable for both the SPND variable and that variable interacted with the DEBT variable. However, the POLR, PRES, and DURA variables are insignificant at a $10 \%$ confidence level in both specifications. More importantly, we reject a weak instrument problem through a battery of tests. ${ }^{11}$

In addition to the strength of our instruments, concern may arise that greater incidence of the pandemic, proxied in our specification by the CV19 variable discussed above, may have led countries more severely impacted by the CV19 pandemic to provide greater fiscal assistance. We therefore also report regressions in appendix Table A4 of the SPND variable and that variable interacted with debt

\footnotetext{
${ }^{11} \mathrm{~F}$-values for the instruments in the first-stage regression are 7.14 and 8.80 for SPND and SPNDXDEBT respectively, indicating overall significance at a $1 \%$ confidence level. We obtain a Stock-Yogo weak ID test value 92.64 and an AR Wald weak instrument F-value of 3.98, both of which reject a weak instrument problem at a $1 \%$ confidence level.
} 
positions going into the pandemic on all of the conditioning variables in our specification. In particular, we find that both variables are negatively correlated with the severity of COVID-19 incidence.

\subsection{Estimation}

Our base specification uses two-stage least squares cross-section estimation, with the four instruments POLR, GVEF, PRES, and DURA utilized for the endogenous variables SPND and SPNDXDEBT. We run this specification with and without the interactive term, as discussed below.

The second stage of our specification with the interactive term included, which we take as our base specification, satisfies

$$
G L O A N_{i j}=c+\beta_{1} S P N D_{j}+\beta_{2} S P N D_{j} x D E B T_{j}+\beta_{3} D E B T_{j}+\beta_{4} X_{i}+\beta_{5} \gamma_{j}+H I C_{j}+U M C_{j}+\varepsilon_{i j}
$$

where

- $G L O A N_{i j}$ is the dependent variable representing growth in lending by bank i in country j,

- $\quad S P N D_{j}$ is government spending above normal as a share of GDP in country $\mathrm{j}$,

- $D E B T_{j}$ is the debt-to-GDP prevailing in country $\mathrm{j}$,

- $S P N D_{j} x D E B T_{j}$ is the interaction of the two previous variables,

- $X_{i}$ is a vector of the bank i specific variables, $B A D L, C A S H, E Q U I$, and $D E P O$

- $\quad \gamma_{j}$ is a vector of the other country $\mathrm{j}$ variables, including $C V 19, P O P N$, and GGDP

- $H I C_{j}$ is a dummy variable which takes value 1 for high-income countries with income per capital exceeding $\mathrm{X}$, and 0 otherwise,

- $U M C_{j}$ is a dummy variable which takes value 1 for upper-middle income countries with income per capital exceeding $\mathrm{Y}$ and less than $\mathrm{X}$, and 0 otherwise, and

- $\varepsilon_{i j}$ represents a residual, assumed to be well-behaved subject to individual estimation details discussed below. 
We have two primary coefficients of interest, $S P N D_{j}$, the direct impact of COVID-related spending on bank lending and $S P N D_{j} x D E B T_{j}$, the interactive term representing the degree to which this impact is influenced by the bank home country's debt position going into the pandemic period. Of course, we are also interested in the coefficient on $D E B T_{j}$, which measures the direct impact of national debt positions going into the pandemic.

\section{Results}

\subsection{Base specification}

Our initial results are shown in Table 2, with our base specification in column 1. $S P N D_{j}$ enters positively, but insignificantly. More importantly, our interactive variable, $S P N D_{j} x D E B T_{j}$ enters significantly negative at close to a $1 \%$ confidence level. Moreover, it is illustrative to consider the two coefficient estimates simultaneously. For example, as shown in Table 1, the sample mean value of $D E B T_{j}$ is 83.59. It follows that for a bank in a country with the mean debt position going into the crisis, our point estimates indicate that a one-standard deviation increase in $S P N D_{j}$ is predicted to result in a 4.75 percentage point decrease in bank lending growth on average. ${ }^{12}$ Our results therefore indicate a meaningful drag on bank lending for countries with average debt positions, and of course, this drag is predicted to be worse for banks in countries that entered the pandemic period in below-average debt positions.

Finally, $D E B T_{j}$ on its own enters positively and significantly at a $5 \%$ confidence level, indicating that lending growth was actually greater among banks in countries that entered the pandemic period

\footnotetext{
${ }^{12}$ The standard deviation of $S P N D_{j}$ is 5.41 , so the calculation is $[0.711-(0.019 \times 83.59)] \times 5.41=-4.75$.
} 
with a higher debt-to-GDP ratio. This finding is somewhat surprising, but perhaps less so when again the interactive term is taken into consideration. As shown in Table 1, the sample mean value of $S P N D_{j}$ is

Table 2. Base Specification.

\begin{tabular}{|c|c|c|c|c|}
\hline & (1) & (2) & (3) & (4) \\
\hline & 1 & 2 & 3 & 4 \\
\hline \multirow[t]{2}{*}{ SPND } & 0.7 & $-0.5^{*}$ & & $0.4^{* * *}$ \\
\hline & $(0.5)$ & $(0.3)$ & & $(0.1)$ \\
\hline \multirow[t]{2}{*}{ SPNDxDEBT } & $-1.9^{* *}$ & & $-1.0^{* * *}$ & $-1.1^{* * *}$ \\
\hline & $(0.7)$ & & $(0.3)$ & (0.1) \\
\hline \multirow[t]{2}{*}{ DEBT } & $27.5^{*}$ & $-2.5^{*}$ & $13.5^{* *}$ & $15.3^{* * *}$ \\
\hline & (11.2) & (1.0) & $(4.3)$ & $(1.4)$ \\
\hline \multirow[t]{2}{*}{ CV19 } & -1.0 & -0.7 & $-1.0^{*}$ & $-0.9^{* * *}$ \\
\hline & $(0.5)$ & $(0.7)$ & $(0.5)$ & $(0.1)$ \\
\hline \multirow[t]{2}{*}{ GGDP } & 0.4 & -0.2 & 0.1 & $0.1^{*}$ \\
\hline & $(0.3)$ & $(0.2)$ & $(0.1)$ & (0.1) \\
\hline \multirow[t]{2}{*}{ POPN } & 0.4 & $0.8^{* * *}$ & $0.6^{* * *}$ & $0.5^{* * *}$ \\
\hline & $(0.2)$ & $(0.1)$ & $(0.1)$ & (0.0) \\
\hline \multirow[t]{2}{*}{$\mathrm{HIC}$} & $12.6^{* * *}$ & $11.5^{* * *}$ & $12.8^{* * *}$ & $8.6^{* * *}$ \\
\hline & $(1.6)$ & $(2.2)$ & $(1.4)$ & $(0.5)$ \\
\hline \multirow[t]{2}{*}{ UMC } & 2.1 & -1.5 & 0.6 & $1.3^{*}$ \\
\hline & $(2.3)$ & (1.6) & (1.4) & (0.5) \\
\hline \multirow[t]{2}{*}{ LGLOAN } & $0.3^{* * *}$ & $0.2^{* * *}$ & $0.2^{* * *}$ & $0.2^{* * *}$ \\
\hline & $(0.0)$ & $(0.0)$ & $(0.0)$ & (0.0) \\
\hline \multirow[t]{2}{*}{ BADL } & $-20.6^{* * *}$ & $-14.1^{*}$ & $-18.7^{* *}$ & $-9.0^{* *}$ \\
\hline & $(6.2)$ & $(6.7)$ & (6.1) & $(2.8)$ \\
\hline \multirow[t]{2}{*}{$\mathrm{CASH}$} & 0.8 & $-6.9^{* *}$ & -3.4 & -0.4 \\
\hline & $(4.0)$ & $(2.6)$ & (2.6) & (1.0) \\
\hline \multirow[t]{2}{*}{ EQUI } & -0.1 & -0.1 & -0.1 & $-0.1^{*}$ \\
\hline & (0.0) & $(0.0)$ & (0.0) & (0.0) \\
\hline \multirow[t]{2}{*}{ DEPO } & $7.3^{* *}$ & 3.5 & $5.6^{* *}$ & $8.9^{* * *}$ \\
\hline & $(2.4)$ & (1.8) & (1.9) & $(0.5)$ \\
\hline \multirow[t]{2}{*}{ Constant } & $-16.7^{*}$ & 2.7 & $-7.0^{*}$ & $-13.0^{* * *}$ \\
\hline & (7.5) & $(2.5)$ & (3.0) & (1.3) \\
\hline $\mathrm{R}^{2}$ & 0.3 & 0.3 & 0.3 & 0.6 \\
\hline Observations & 3297 & 3297 & 3297 & 3297 \\
\hline
\end{tabular}

Note: Standard errors, clustered by country, are in parentheses. Each column shows the estimates based on the single-equation instrumental-variables regression. The endogenous variables are COVID-19 fiscal spending and its interaction with public debt/GDP; SPND and SPNDxDEBT, and the instruments are political-economy variables; POLR, GVEF, PRES, and DURA; using the 2SLS estimator. Column (4) is done with the weighted least squares, with observations weighted by bank total assets.

${ }^{*} p<0.05,{ }^{* *} p<0.01,{ }^{* * *} p<0.001$ 
10.24. It follows that for a bank in a country with the mean debt position going into the crisis, our point estimates indicate that a one-standard deviation increase in $D E B T_{j}$ is predicted to result in a 5.04 percentage point increase in bank lending growth on average. ${ }^{13}$ However, it should be stressed that this is the average result. As spending increases the coefficient on $D E B T_{j}$ also turns negative. For example, a one standard deviation increase in $S P N D_{j}$ reduces the point estimate of the net impact of a one standard deviation increase in $D E B T_{j}$ to - 01.67. For a bank in such a high government spending country, therefore, a one standard deviation increase in the initial debt position would be predicted to reduce lending by 1.05 percentage points on average. While the coefficient on $D E B T_{j}$ is positive, then, the negative interactive term implies that banks from countries with high values of both $S P N D_{j}$ and $D E B T_{j}$ had lower lending growth on average.

Our conditioning variables enter as predicted. Among the bank-specific variables, $L G_{i}$ enters significantly positively at a $1 \%$ confidence level, as banks with more rapid growth in 2019 also experienced more rapid growth on average in 2020. In contrast, $B A D L_{i}$ enters significantly negatively, also at a $1 \%$ confidence level, as banks that entered 2020 with inferior balance sheet positions had lower lending growth on average. $\mathrm{CASH}_{i}$ is insignificant, as low bank liquidity might be indicative of a lending constraint, but also could identify banks with greater willingness to maintain riskier lending practices, which would push in the opposite direction during the pandemic period. Similarly, $E Q U I_{i}$ enters negatively significant at a $10 \%$ confidence level. As was the case with the $C A S H_{i}$ variable, bank capital ratios may either indicate a greater capacity to increase lending, or a lower willingness to do so. Finally,

\footnotetext{
${ }^{13}$ The standard deviation of $D E B T_{j}$ is 62.67 , so the calculation is $[0.275-(0.19 \times 10.24)] \times 62.67=5.04$
} 
$D E P O_{i}$ enters positively and significantly at a $1 \%$ confidence level, indicating more rapid lending growth among more conventional banks during the pandemic period.

In terms of our macro variables, $G G D P_{j}$ enters positively, as would be expected, but statistically insignificant. $C_{j}$ enters negatively, as expected, and statistically significantly at a $10 \%$ confidence level, indicating that greater incidence of the COVID-19 virus was associated with reduced lending growth on average ${ }^{14}$ Country size, as measured by $P O P_{j}$, is positively associated with lending growth, but insignificant, while our wealthy country dummies, $H I C_{j}$ and $U M C_{j}$ both enter positively, but with the high-income group significant at a $1 \%$ level with a point estimate close to six times the size of that on the upper-middle country group, which enters insignificantly.

We next consider the two endogenous variables $S P N D_{j}$ and $S P N D_{j} x D E B T_{j}$ one at a time in columns 2 and 3. Our results indicate a negative and statistically significant direct impact of $S P N D_{j}$ suggesting that countries which undertook larger fiscal stimulus programs under COVID-19 experienced lower bank lending growth. Moreover, our coefficient point estimate indicates that the impact is economically significant, with a one standard deviation increase in $S P N D_{j}$ predicted to be associated with a 2.76 percentage point decline in bank lending growth on average. We also find that with the exclusion of the interactive term the $D E B T_{j}$ variable enters significantly negative at a $1 \%$ confidence level. Our point estimate indicates that a one standard deviation increase in $D E B T_{j}$ is predicted to result in a 1.57 percentage point decline in bank lending growth on average. The conditioning variable estimates tend to be similar to those in our base specification in terms of sign, although standard errors and significance can vary.

\footnotetext{
${ }^{14}$ This finding is consistent with those of Çolak and Öztekin (2021), who find that bank lending during the pandemic period was weaker in countries that were more severely affected by the health crisis.
} 
Column 3 indicates a negative and statistically significant effect of the interactive variable $S P N D_{j} x D E B T_{j}$ with the individual variables excluded. Moreover, as the sample mean of the predetermined $D E B T_{j}$ variable is 62.67 , our point estimate for the interactive variable is also economically meaningful, with a one standard deviation increase in the $S P N D_{j}$ variable for a country that enters the pandemic in the mean debt position predicted to be associated with a 3.39 percentage point decrease in lending growth, quite similar to the results we obtain in our base specification.

Finally, to gauge the possibility that differences in sensitivity to government spending may differ by bank size, we rerun our base specification in column 4 under weighted least squares, with observations weighted by bank total assets. Our results are qualitatively the same as those that we obtain in our base column 1 specification. In particular, combining our point estimates for $S P N D_{j}$ and $S P N D_{j} x D E B T_{j}$ we find that under weighted least squares our point estimates indicate that a one standard deviation increase in $S P N D_{j}$ for a country that entered the pandemic with the mean sample value of $D E B T_{j}$ would be predicted to result in a 2.81 percentage point decline in bank lending growth on average. Consequently, while our estimated standard errors are reduced with weighted least square estimation, it would be misleading that the comparison suggests that the results are "stronger" for larger banks. Indeed, after weighing by bank size, the absolute value of our point estimate on the interactive term is reduced from 0.017 to 0.011 .

\subsection{Differences by income groups}

Our base specification results suggested that disparities in loan growth rates existed between banks from different country income groups. We therefore separated our sample by income groups to allow for disparities by income group in sensitivity to differences in government spending programs. As above, we run each sample with and without the interactive term. As the number of banks with full data available from low-income countries is modest, we pool the sample of banks from low and lower 
middle-income countries. For space purposes, we only report our point estimates for our variables of interest, but the full regression results are available upon request.

Our results are shown in Table 3. As discussed above, the high-income sub-sample is the largest in our banking data, with 2,307 observations. Column 1 reports our results with the interactive term included. As in our full sample, $S P N D_{j}$ enters insignificantly with a positive coefficient estimate, while the interactive term $S P N D_{j} x D E B T_{j}$ is negative and significant at a $1 \%$ confidence level. Our coefficient point estimates are also very similar to those we obtain in our full sample, indicating a net decline in lending growth for a nation with the mean value of $D E B T_{j}$ for a one standard deviation increase in $S P N D_{j}$. Also in keeping with our full sample results, the $D E B T_{j}$ variable enters positively and significantly, again with a point estimate very similar to that which we obtained for our full sample.

High-income country sub-sample results with the interactive term removed are reported in Column 2. Here again, the results are quite similar to those we obtain in our full sample. With the interactive term excluded, we again obtain a negative and statistically significant at a $5 \%$ confidence level coefficient on $S P N D_{j}$, indicating that government spending is a drag on bank lending growth. We also, as before, obtain a statistically significant negative coefficient estimate on $D E B T_{j}$, indicating that elevated government debt-to-GDP ratios dragged on bank lending as well during the pandemic period. The point estimates for these variables are qualitatively similar to those we obtained in our base specification. ${ }^{15}$ The other sub-samples are substantively smaller. We have 569 observations for banks from Upper-middle-income countries, with results shown in columns 3 and 4. Column 3 repeats our base specification for this sub-sample with the interactive term $S P N D_{j} x D E B T_{j}$ included. This term

\footnotetext{
${ }^{15}$ The results for the conditioning variables were also similar to those is our base specifications, and for space purposes are available upon request.
} 
Table 3. Base Specification by Country's Income Group.

\begin{tabular}{|c|c|c|c|c|c|c|}
\hline & (1) & (2) & (3) & (4) & (5) & (6) \\
\hline & $\mathrm{HIC}$ & HIC & UMC & UMC & LMIC & LMIC \\
\hline \multirow[t]{2}{*}{ SPND } & 0.6 & -0.6 & 0.9 & -1.8 & -1.3 & $-0.6^{* *}$ \\
\hline & $(0.5)$ & $(0.3)$ & $(4.4)$ & $(1.6)$ & $(1.3)$ & $(0.2)$ \\
\hline \multirow[t]{2}{*}{ SPNDxDEBT } & $-1.8^{* * *}$ & & -5.5 & & 2.1 & \\
\hline & $(0.5)$ & & (9.1) & & (3.9) & \\
\hline \multirow[t]{2}{*}{ DEBT } & $25.2^{* *}$ & $-4.1^{* * *}$ & 44.9 & 1.9 & -6.3 & -2.0 \\
\hline & $(8.4)$ & $(0.9)$ & (70.1) & $(7.6)$ & (9.6) & $(2.1)$ \\
\hline \multirow[t]{2}{*}{ CV19 } & -0.5 & 0.5 & -3.5 & -4.0 & 0.3 & 0.2 \\
\hline & $(1.0)$ & $(1.3)$ & $(2.9)$ & $(2.7)$ & $(0.5)$ & $(0.4)$ \\
\hline \multirow[t]{2}{*}{ GGDP } & 0.6 & -0.1 & 0.9 & 0.1 & $0.4^{* *}$ & $0.4^{* * *}$ \\
\hline & $(0.4)$ & $(0.4)$ & $(1.5)$ & $(0.5)$ & $(0.1)$ & $(0.1)$ \\
\hline \multirow[t]{2}{*}{ POPN } & 3.2 & $7.3^{*}$ & -0.3 & 0.1 & -1.0 & -1.2 \\
\hline & (3.6) & (3.0) & $(1.1)$ & $(0.6)$ & $(0.8)$ & $(0.8)$ \\
\hline \multirow[t]{2}{*}{ LGLOAN } & $0.3^{* * *}$ & $0.2^{* * *}$ & $0.3^{* *}$ & $0.2^{* *}$ & $0.2^{* * *}$ & $0.2^{* * *}$ \\
\hline & $(0.0)$ & $(0.0)$ & $(0.1)$ & $(0.1)$ & $(0.0)$ & $(0.1)$ \\
\hline \multirow[t]{2}{*}{ BADL } & $-19.3^{*}$ & -14.6 & 6.7 & -3.4 & $-27.6^{* *}$ & $-26.7^{* *}$ \\
\hline & $(9.4)$ & (10.9) & (19.5) & $(11.0)$ & $(10.0)$ & $(10.3)$ \\
\hline \multirow[t]{2}{*}{$\mathrm{CASH}$} & -3.3 & -6.5 & -14.0 & -12.6 & -2.8 & -1.7 \\
\hline & $(3.4)$ & (3.6) & $(16.6)$ & $(14.7)$ & $(4.5)$ & (3.7) \\
\hline \multirow[t]{2}{*}{ EQUI } & 0.0 & -0.0 & $-0.2^{* * *}$ & $-0.2^{* * *}$ & 0.0 & 0.0 \\
\hline & $(0.1)$ & $(0.1)$ & $(0.1)$ & $(0.1)$ & $(0.1)$ & $(0.1)$ \\
\hline \multirow[t]{2}{*}{ DEPO } & 4.7 & 1.0 & 6.2 & $7.4^{* *}$ & 3.2 & 3.4 \\
\hline & $(2.4)$ & $(2.1)$ & (3.7) & $(2.9)$ & $(3.7)$ & (3.6) \\
\hline \multirow[t]{2}{*}{ Constant } & -3.0 & $13.9^{* * *}$ & -3.0 & 13.8 & 5.7 & 3.9 \\
\hline & $(5.8)$ & (3.0) & $(28.2)$ & $(16.4)$ & $(6.2)$ & $(5.0)$ \\
\hline$\overline{R^{2}}$ & 0.2 & 0.2 & 0.2 & 0.2 & 0.2 & 0.2 \\
\hline Observations & 2307 & 2307 & 569 & 569 & 421 & 421 \\
\hline
\end{tabular}

Note: Standard errors, clustered by country, are in parentheses. HIC High-income; UMC Upper-middle-income; LMIC Lower-middle and Low-income. Each column shows the estimates based on the single-equation instrumental-variables regression. The endogenous variables are COVID-19 fiscal spending and its interaction with public debt/GDP; SPND and SPNDxDEBT, and the instruments are political-economy variables; POLR, GVEF, PRES, and DURA; using the 2SLS estimator.

${ }^{*} p<0.05,{ }^{* *} p<0.01,{ }^{* * *} p<0.001$

continues to enter negatively, and indeed obtains a substantively larger point estimate than it

did in either our full sample or our sub-sample of banks from high-income countries. However, it is statistically insignificant. As in our full sample, with the interactive term included the $S P N D_{j}$ variable on 
its own enters insignificantly positive, while the $D E B T_{j}$ variable on its own continues to enter positively, but is now insignificant as well. Column 4 reports the results for our upper-middle-income country subsample with the interactive term removed. Both the $S P N D_{j}$ variable and the $D E B T_{j}$ variable enter insignificantly.

We have 421 observations for banks from either lower middle-income or low-income countries. Our results are shown in columns 5 and 6 , with the interactive term included and excluded respectively. With the interactive term included, all of the variables of interest are insignificant. However, with the interactive term excluded in column 6 the results are more in keeping with those in our full sample. Both the $S P N D_{j}$ variable and the $D E B T_{j}$ variable enter negatively. However, while the $S P N D_{j}$ variable obtains coefficient point estimates qualitatively similar to those in our full sample, and is again statistically significant at a $1 \%$ confidence level, our $D E B T_{j}$ variable enters with a lower coefficient estimate and is now statistically insignificant.

Overall, our results from sub-samples by country income levels suggest that our full-sample results are primarily driven by banks from high-income countries, while the results for banks from upper middle and lower middle and lower income samples are generally weaker.

\subsection{Difference by bank size, funding strategies, and financial strength}

As discussed above, there is reason to believe that the importance of implicit and explicit government guarantees under the COVID-19 pandemic may vary systematically by bank size and activity. We therefore examine the performances of sub-samples by banking size and funding strategy. We characterize large banks as those with assets exceeding $\$ 100$ billion, small banks as those with assets less than $\$ 10$ billion, and medium-sized banks as those with assets in between. We characterize 
high-deposit banks as those with deposit-to-total funding ratios greater than 0.75 , and low-deposit banks as those below 0.75 .

Our results are shown in Table 4. For space considerations, we only report our base specification with the interactive term included. We first consider sub-samples by bank size, in columns 1 through 3 . Note that sample size varies substantively, with the large banks sample very small at 185 observations, the medium-sized bank sample somewhat larger, at 690 observations, and the "small" bank sample the largest, at 2,422 observations. Note that while the large bank sample is small in number (5\%), it is important as they comprise 77 percent of total assets in our full sample.

We find that the interactive term $S P N D_{j} x D E B T_{j}$ enters negatively for all three sub-samples by size. The coefficient point estimate is smallest for the large bank sample, at -0.007 , and it misses statistical significance at conventional confidence levels. However, the term enters statistically significantly for the medium and small bank sub-samples, with the largest point estimate for the medium-sized bank sub-sample, which enters with a point estimate of -0.024 at a statistically significant $1 \%$ confidence level, while the coefficient estimate for the small bank sub-sample enters with a point estimate of -0.017 , also statistically significant at a $1 \%$ confidence level. The $S P N D_{j}$ and $D E B T_{j}$ variables enter positively, as before, with the $S P N D_{j}$ variable statistically insignificant, while for the small and medium-sized sub-samples the $D E B T_{j}$ variables are statistically significant at $5 \%$ and $1 \%$ confidence levels respectively.

Overall, then, we find that our full sample results indicating a negative relationship between growth in lending by banks in countries and high spending and government debt levels was most pronounced for the medium and smaller banks in our sample. Our results for banks split by reliance on deposit funding are shown in columns 4 and 5 . Here again, there is a discrepancy in sample size, as 
Table 4. Results by Bank's Size and Deposit Funding.

\begin{tabular}{|c|c|c|c|c|c|c|c|}
\hline & $\begin{array}{c}\text { (1) } \\
\text { Large }\end{array}$ & $\begin{array}{l}(2) \\
\text { Mid }\end{array}$ & $\begin{array}{c}(3) \\
\text { Small }\end{array}$ & $\begin{array}{c}\text { (4) } \\
\text { High- } \\
\text { Deposit }\end{array}$ & $\begin{array}{c}\text { (5) } \\
\text { Low- } \\
\text { Deposit }\end{array}$ & $\begin{array}{c}\text { (6) } \\
\text { BLHI }\end{array}$ & $\begin{array}{c}(7) \\
\text { BLLO }\end{array}$ \\
\hline \multirow[t]{2}{*}{ SPND } & 0.1 & 0.4 & 0.5 & -0.5 & 0.9 & 0.5 & 0.3 \\
\hline & $(0.4)$ & $(0.5)$ & $(0.4)$ & $(0.7)$ & $(0.5)$ & $(0.6)$ & $(0.4)$ \\
\hline \multirow[t]{2}{*}{ SPNDxDEBT } & -0.6 & $-1.9^{* *}$ & $-1.7^{* *}$ & -0.6 & $-2.1^{*}$ & $-1.8^{*}$ & $-1.2^{*}$ \\
\hline & (0.5) & $(0.7)$ & $(0.6)$ & $(0.7)$ & $(0.9)$ & $(0.8)$ & $(0.6)$ \\
\hline \multirow[t]{2}{*}{ DEBT } & 7.6 & $28.9^{*}$ & $23.3^{*}$ & 9.2 & $29.7^{*}$ & $26.2^{*}$ & 16.2 \\
\hline & (8.0) & (11.6) & (9.9) & (9.1) & (14.3) & $(12.2)$ & (9.6) \\
\hline \multirow[t]{2}{*}{ CV19 } & -0.5 & $-2.1^{*}$ & -0.7 & $-2.1^{*}$ & -0.9 & -1.3 & -0.7 \\
\hline & $(0.7)$ & $(0.8)$ & $(0.6)$ & (1.0) & $(0.6)$ & $(0.7)$ & $(0.5)$ \\
\hline \multirow[t]{2}{*}{ GGDP } & -0.0 & -0.1 & 0.5 & -0.3 & 0.6 & 0.3 & 0.3 \\
\hline & $(0.3)$ & $(0.3)$ & $(0.3)$ & $(0.3)$ & $(0.4)$ & $(0.4)$ & $(0.3)$ \\
\hline \multirow[t]{2}{*}{ POPN } & $0.7^{* * *}$ & 0.4 & 0.3 & $0.7^{* * *}$ & 0.3 & 0.3 & $0.6^{* * *}$ \\
\hline & $(0.1)$ & $(0.2)$ & $(0.2)$ & $(0.2)$ & $(0.3)$ & $(0.3)$ & $(0.2)$ \\
\hline \multirow[t]{2}{*}{$\mathrm{HIC}$} & $6.2^{* * *}$ & $11.5^{* * *}$ & $13.5^{* * *}$ & $12.0^{* * *}$ & $12.6^{* * *}$ & $13.4^{* * *}$ & $11.0^{* * *}$ \\
\hline & $(1.6)$ & $(2.7)$ & $(1.5)$ & (3.0) & $(2.0)$ & $(2.7)$ & (1.4) \\
\hline \multirow[t]{2}{*}{ UMC } & 0.0 & 4.5 & 1.1 & -1.4 & 3.4 & 3.9 & -2.4 \\
\hline & (.) & $(2.6)$ & $(2.2)$ & $(2.0)$ & $(2.8)$ & $(3.1)$ & (1.4) \\
\hline \multirow[t]{2}{*}{ LGLOAN } & -0.0 & $0.3^{* *}$ & $0.3^{* * *}$ & $0.3^{* * *}$ & $0.2^{* * *}$ & $0.2^{* * *}$ & $0.2^{* * *}$ \\
\hline & $(0.1)$ & $(0.1)$ & $(0.0)$ & $(0.1)$ & $(0.0)$ & $(0.0)$ & $(0.0)$ \\
\hline \multirow[t]{2}{*}{ BADL } & -39.6 & -13.3 & $-20.4^{* * *}$ & -11.8 & $-21.1^{* *}$ & $-18.0^{* *}$ & 26.7 \\
\hline & (21.0) & (17.3) & (5.7) & (6.9) & (6.5) & (6.5) & (32.8) \\
\hline \multirow[t]{2}{*}{$\mathrm{CASH}$} & -1.4 & -3.2 & 1.4 & -10.0 & 1.9 & 0.2 & 0.2 \\
\hline & $(4.5)$ & (4.9) & (3.7) & (7.3) & $(4.4)$ & $(5.8)$ & (3.0) \\
\hline \multirow[t]{2}{*}{ EQUI } & -0.2 & -0.1 & -0.1 & -0.1 & -0.1 & $-0.1^{* *}$ & -0.0 \\
\hline & $(0.2)$ & $(0.1)$ & $(0.1)$ & $(0.1)$ & (0.1) & $(0.1)$ & $(0.1)$ \\
\hline \multirow[t]{2}{*}{ DEPO } & $10.7^{* * *}$ & 6.9 & $5.7^{*}$ & $9.4^{* *}$ & 4.1 & $7.1^{*}$ & $6.0^{* *}$ \\
\hline & $(2.3)$ & (3.6) & $(2.5)$ & (2.9) & (6.4) & $(3.2)$ & $(2.2)$ \\
\hline \multirow[t]{2}{*}{ Constant } & -6.1 & -15.4 & $-13.6^{*}$ & -4.2 & -15.7 & -15.3 & -9.7 \\
\hline & $(5.0)$ & (8.4) & $(6.2)$ & $(7.6)$ & $(11.7)$ & $(8.7)$ & $(6.2)$ \\
\hline $\mathrm{R}^{2}$ & 0.6 & 0.4 & 0.3 & 0.4 & 0.3 & 0.2 & 0.4 \\
\hline Observations & 162 & 679 & 2456 & 836 & 2461 & 1595 & 1702 \\
\hline
\end{tabular}

Note: Standard errors, clustered by country, are in parentheses. 'Large' refers to total assets greater than \$100B; 'Small' for less than \$10B. 'High-Deposit' refers to deposits/total funding of more than 0.75. BLHI and BLLO estimate high banks with high and low shares of bad loans respectively. Each column shows the estimates based on the single-equation instrumental-variables regression. The endogenous variables are COVID-19 fiscal spending and its interaction with public debt/GDP; SPND and SPNDxDEBT, and the instruments are political-economy variables; POLR, GVEF, PRES, and DURA; using the 2SLS estimator.

${ }^{*} p<0.05,{ }^{* *} p<0.01,{ }^{* * *} p<0.001$ 
banks designated as "high deposit" constitute 2,439 observations, while our low deposit bank subsample is smaller, at 858 observations.

Our results for the high deposit sample are quite similar to those for our full sample. The interactive term $S P N D_{j} x D E B T_{j}$ enters negatively at a $5 \%$ confidence level with a point estimate qualitatively similar to that in our full sample. The $S P E N D_{j}$ and $D E B T_{j}$ variables enter positively with the former insignificant, also as in our full sample. The latter variable is statistically significant at a $10 \%$ confidence level, with a point estimate comparable to our base specification results.

Our results for the low deposit sub-sample are somewhat different. We continue to obtain a negative and statistically significant coefficient estimate for our interactive variable, $S P N D_{j} x D E B T_{j}$, with a modestly smaller point estimate. However, the point estimate for the $S P N D_{j}$ variable is much smaller and statistically insignificant. As a result, our point estimates indicate that the net impact of a one standard deviation increase in the $S P N D_{j}$ variable for low-deposit banks with our sample with a mean debt position for that group of 76.12 will experience on average a 5.45 percentage point decrease in lending growth. This figure is 70 basis points above that which we obtained for our base specification. We also obtain a somewhat smaller positive coefficient on the $D E B T_{j}$ variable, although it remains statistically significant at a $5 \%$ confidence level.

Finally, we separate our sample into weaker and stronger bank sub-samples, with bank strength proxied by higher and lower shares of bad loans to total assets. We continue to obtain negative and statistically significant coefficient estimate for our interactive variable, $S P N D_{j} x D E B T_{j}$, in both subsamples. However, the point estimate on the interactive term is substantively higher for the weal bank sub-sample than for the strong bank sub-sample, -0.018 vs -0.013 respectively. This indicates that the 
relationship between fiscal stimulus and bank lending growth is more sensitive to national fiscal positions among weaker than stronger banks.

Overall, our results from separating the sample by bank type indicate that our full sample results are primarily driven by the smaller and high deposit banks in our sample, characteristics that typically correspond to more conventional banking firms, and are stronger for weaker banks. We view these results as supportive of the hypothesis that bank responses to fiscal spending are influenced by their perception of the probability of government assistance going forward, as weaker banks are more likely than strong ones to need such assistance, holding all else equal.

\section{Robustness checks}

\section{5a. Changes in specification}

Finally, we subject our results to a battery of robustness tests. First, Table 5a examines some changes in our base specification. Columns 1 and 2 substitute the bank capital ratio and the leverage ratio for our equity ratio variable respectively. Our results are qualitatively robust to these specification changes, with coefficient estimates of the same order of magnitude and entering at similar levels of statistical significance as those in our base specification.

We need consider the robustness of our results to the omission of our conditioning variables. Column 3 drops all our bank conditioning variables. It can be seen that our qualitative results are robust to the exclusion of these variables, although the coefficient estimates on the $S P E N D_{j} x D E B T_{j}$ variables are only significant at a $10 \%$ confidence level, while those on the variables individually become insignificant. In the Appendix Table A5, we drop the bank conditioning variables one at a time, and show that our qualitative results are quite robust to the exclusion of any individual bank conditioning variable in our specification, as our point estimates and estimated statistical significance are similar to those in our base specification. 
Table 5a. Robustness checks: perturbations in specification.

\begin{tabular}{|c|c|c|c|c|c|c|}
\hline & $(1)$ & (2) & (3) & (4) & (5) & (6) \\
\hline \multirow[t]{2}{*}{ SPND } & 1.0 & 0.8 & 0.5 & 0.2 & -1.6 & -0.1 \\
\hline & $(0.6)$ & $(0.5)$ & $(0.5)$ & $(0.5)$ & (2.2) & $(0.5)$ \\
\hline \multirow[t]{2}{*}{ SPNDXDEBT } & $-2.0^{*}$ & $-2.1^{* *}$ & -1.3 & -1.0 & 7.1 & \\
\hline & (0.9) & $(0.8)$ & $(0.7)$ & $(0.6)$ & (9.1) & \\
\hline \multirow[t]{2}{*}{ DEBT } & $28.4^{*}$ & $29.4^{*}$ & 17.8 & 12.7 & -92.6 & 7.1 \\
\hline & $(14.4)$ & $(12.0)$ & $(11.6)$ & (8.4) & $(133.8)$ & $(16.5)$ \\
\hline \multirow[t]{2}{*}{ SPNDXDEBT2 } & & & & & -4.8 & -0.2 \\
\hline & & & & & (6.2) & $(0.8)$ \\
\hline \multirow[t]{2}{*}{ DEBT2 } & & & & & 69.4 & -0.1 \\
\hline & & & & & $(98.9)$ & $(18.1)$ \\
\hline \multirow[t]{2}{*}{ CV19 } & -0.5 & -1.0 & -1.0 & & -1.0 & -0.2 \\
\hline & (0.7) & $(0.6)$ & $(0.5)$ & & (1.5) & $(0.6)$ \\
\hline \multirow[t]{2}{*}{ GGDP } & 0.5 & 0.4 & 0.4 & & 0.8 & 0.3 \\
\hline & $(0.3)$ & $(0.3)$ & $(0.3)$ & & $(0.8)$ & $(0.2)$ \\
\hline \multirow[t]{2}{*}{ POPN } & 0.4 & 0.4 & $0.5^{*}$ & & 0.4 & $0.6^{* * *}$ \\
\hline & $(0.3)$ & $(0.3)$ & $(0.3)$ & & (0.4) & $(0.1)$ \\
\hline \multirow[t]{2}{*}{ HIC } & $11.2^{* * *}$ & $12.5^{* * *}$ & $12.0^{* * *}$ & $9.6^{* * *}$ & 2.8 & $9.8^{* * *}$ \\
\hline & $(2.1)$ & $(1.7)$ & $(1.6)$ & $(1.8)$ & $(9.2)$ & $(2.3)$ \\
\hline \multirow[t]{2}{*}{ UMC } & 2.7 & 2.3 & 0.6 & 1.2 & -0.1 & -0.1 \\
\hline & $(3.2)$ & (2.5) & (2.3) & $(2.2)$ & (3.5) & $(1.8)$ \\
\hline \multirow{2}{*}{ LGLOAN } & $0.2^{* * *}$ & $0.3^{* * *}$ & & $0.2^{* * *}$ & 0.1 & $0.2^{* * *}$ \\
\hline & $(0.0)$ & $(0.0)$ & & $(0.0)$ & $(0.1)$ & $(0.0)$ \\
\hline \multirow[t]{2}{*}{ BADL } & $-19.4^{* *}$ & $-20.9^{* * *}$ & & $-25.3^{* * *}$ & $-26.0^{*}$ & $-16.4^{* *}$ \\
\hline & $(6.8)$ & $(6.0)$ & & (6.5) & (12.6) & (5.3) \\
\hline \multirow{2}{*}{ CASH } & 3.9 & 1.5 & & -3.0 & 2.1 & -1.1 \\
\hline & (5.4) & (4.4) & & (3.6) & (7.6) & (3.2) \\
\hline \multirow[t]{2}{*}{ DEPO } & $9.4^{* *}$ & $7.7^{* *}$ & & $6.6^{* *}$ & $6.2^{*}$ & $6.7^{* * *}$ \\
\hline & (3.2) & (2.6) & & (2.4) & (2.6) & (1.9) \\
\hline \multirow[t]{2}{*}{ CAPR } & -0.0 & & & & -0.0 & -0.0 \\
\hline & $(0.0)$ & & & & $(0.0)$ & $(0.0)$ \\
\hline \multirow[t]{2}{*}{ LEVR } & & $0.1^{*}$ & & & & \\
\hline & & $(0.0)$ & & & & \\
\hline \multirow[t]{2}{*}{ EQUI } & & & & $-0.1^{*}$ & & \\
\hline & & & & $(0.1)$ & & \\
\hline \multirow[t]{2}{*}{ Constant } & $-22.3^{*}$ & $-20.2^{*}$ & -7.0 & -7.6 & 23.1 & $-8.1^{*}$ \\
\hline & $(9.8)$ & $(8.4)$ & (6.1) & (7.2) & $(38.2)$ & (3.2) \\
\hline R2 & 0.3 & 0.3 & 0.3 & 0.3 & 0.1 & 0.4 \\
\hline $\mathrm{N}$ & 2731 & 3297 & 3297 & 3297 & 2731 & 2731 \\
\hline
\end{tabular}

Note: Standard errors, clustered by country, are in parentheses. Each column shows the estimates based on the single-equation instrumental-variables regression. DEBT2 refers to the square of DEBT. The endogenous variables are COVID-19 fiscal spending and its interaction with public debt/GDP; SPND, SPNDxDEBT, and SPNDxDEBT2, and the instruments are political-economy variables; POLR, GVEF, PRES, and DURA; using the 2SLS estimator.

${ }^{*} p<0.05,{ }^{* *} p<0.01,{ }^{* * *} p<0.001$ 
Column 4 similarly drops all our country conditioning variables. Our results are again qualitatively similar to those in our base, with our variables of interest retaining their sign estimates and entering with similar point estimates. However, we again see that the significance of our variables of interest are reduced, with our interactive term entering statistically significant at a $10 \%$ confidence level. We also dropped the individual country conditioning variables one at a time.

Columns 5 and 6 allow for a nonlinear role for government debt. Some have argued that the magnitude of government debt only becomes a problem after debt levels reach a certain threshold relative to output [e.g. Reinhart and Rogoff (2010)]. In our case, such a relationship would call for a nonlinear relationship between debt levels and the efficacy of government spending in enhancing bank lending growth.

To examine this possibility, we introduce a term, DEBT2, equal to the square of DEBT, as well as that term interacted with the SPND variable SPNDxDEBT2 in columns 5 and 6 . Column 5 adds those two variables, while column 6 also adds those variable, but removes the original linear interactive term SPNDXDEBT. This variable is positively correlated with the SPNDXDEBT2 variable.

Our results show some support for the possibility of a nonlinear relationship, in the sense that in both specifications the nonlinear interactive term SPNDxDEBT2 enters with a negative point estimate. However, the term in statistically insignificant in both specifications, implying that there is only weak evidence in our study for such a nonlinear relationship. 
Table 5b. Robustness checks: changes in estimation method.

\begin{tabular}{|c|c|c|c|c|c|}
\hline & (1) & $\begin{array}{c}\text { (2) } \\
\text { IV-WHITE }\end{array}$ & $\begin{array}{c}\text { (3) } \\
\text { IV-STD }\end{array}$ & $\begin{array}{c}\text { (4) } \\
\text { IV-CL-INC }\end{array}$ & $\begin{array}{c}\text { (5) } \\
\text { TRIM }\end{array}$ \\
\hline \multirow[t]{2}{*}{$\overline{S P N D}$} & 0.2 & $0.7^{* * *}$ & $0.7^{* * *}$ & $0.7^{* * *}$ & 0.7 \\
\hline & $(0.2)$ & $(0.2)$ & $(0.2)$ & $(0.1)$ & (0.5) \\
\hline \multirow[t]{2}{*}{ SPNDxDEBT } & $-0.8^{* * *}$ & $-1.9^{* * *}$ & $-1.9^{* * *}$ & $-1.9^{* * *}$ & $-1.9^{* *}$ \\
\hline & $(0.2)$ & $(0.3)$ & $(0.2)$ & $(0.3)$ & (0.7) \\
\hline \multirow[t]{2}{*}{ DEBT } & $10.3^{* *}$ & $27.5^{* * *}$ & $27.5^{* * *}$ & $27.5^{* * *}$ & $27.5^{*}$ \\
\hline & (3.0) & (4.3) & (3.3) & (4.1) & (11.2) \\
\hline \multirow[t]{2}{*}{ CV19 } & -0.6 & $-1.0^{* * *}$ & $-1.0^{* * *}$ & $-1.0^{* * *}$ & -1.0 \\
\hline & $(0.5)$ & $(0.2)$ & $(0.2)$ & (0.3) & $(0.5)$ \\
\hline \multirow[t]{2}{*}{ GGDP } & 0.2 & $0.4^{* * *}$ & $0.4^{* * *}$ & $0.4^{* * *}$ & 0.4 \\
\hline & (0.1) & $(0.1)$ & $(0.1)$ & $(0.1)$ & (0.3) \\
\hline \multirow[t]{2}{*}{ POPN } & $0.6^{* * *}$ & $0.4^{* * *}$ & $0.4^{* * *}$ & $0.4^{* *}$ & 0.4 \\
\hline & (0.1) & (0.1) & (0.1) & (0.1) & $(0.2)$ \\
\hline \multirow[t]{2}{*}{ HIC } & $11.1^{* * *}$ & $12.6^{* * *}$ & $12.6^{* * *}$ & $12.6^{* * *}$ & $12.6^{* * *}$ \\
\hline & (1.6) & (0.7) & $(0.6)$ & $(0.8)$ & (1.6) \\
\hline \multirow[t]{2}{*}{ UMC } & -0.1 & $2.1^{*}$ & $2.1^{* * *}$ & 2.1 & 2.1 \\
\hline & (1.3) & $(0.9)$ & $(0.6)$ & (1.2) & (2.3) \\
\hline \multirow[t]{2}{*}{ LGLOAN } & $0.2^{* * *}$ & $0.3^{* * *}$ & $0.3^{* * *}$ & $0.3^{* * *}$ & $0.3^{* * *}$ \\
\hline & $(0.0)$ & $(0.0)$ & $(0.0)$ & $(0.0)$ & $(0.0)$ \\
\hline \multirow[t]{2}{*}{ BADL } & $-15.7^{* *}$ & $-20.6^{* * *}$ & $-20.6^{* * *}$ & $-20.6^{* * *}$ & $-20.6^{* * *}$ \\
\hline & (5.8) & (3.8) & (2.5) & (3.2) & (6.2) \\
\hline \multirow[t]{2}{*}{$\mathrm{CASH}$} & -3.0 & 0.8 & 0.8 & 0.8 & 0.8 \\
\hline & (2.7) & (1.9) & (1.5) & (3.6) & $(4.0)$ \\
\hline \multirow[t]{2}{*}{ EQUI } & -0.1 & $-0.1^{*}$ & $-0.1^{* * *}$ & -0.1 & -0.1 \\
\hline & $(0.0)$ & $(0.0)$ & $(0.0)$ & (0.1) & $(0.0)$ \\
\hline \multirow[t]{2}{*}{ DEPO } & $5.0^{*}$ & $7.3^{* * *}$ & $7.3^{* * *}$ & $7.3^{* * *}$ & $7.3^{* *}$ \\
\hline & (1.9) & (1.1) & (0.8) & (1.7) & (2.4) \\
\hline \multirow[t]{2}{*}{ Constant } & $-6.3^{*}$ & $-16.7^{* * *}$ & $-16.7^{* * *}$ & $-16.7^{* * *}$ & $-16.7^{*}$ \\
\hline & (2.8) & (3.0) & (2.3) & (2.5) & (7.5) \\
\hline$\overline{R^{2}}$ & 0.4 & 0.3 & 0.3 & 0.3 & 0.3 \\
\hline Observations & 3297 & 3297 & 3297 & 3297 & 3297 \\
\hline
\end{tabular}

Note: Standard errors, clustered by country, are in parentheses. Column (1) estimated with ordinary least squares. Column (2), IV-WHITE, IV estimation with White standard errors. Column (3), IV-STD, IV with conventional standard errors. Column (4), IV-CL-INC, refers to IV with standard errors clustered by income group. TRIM refers to a sample with all variables trimmed at the 1st and 99th percentiles rather than winsorized. Endogenous variables under 2SLS IV estimation include COVID-19 fiscal spending and its interaction with public debt/GDP, SPND and SPNDXDEBT. See text for definitions of political-economy instruments; POLR, GVEF, PRES, and DURA. ${ }^{*} p<0.05,{ }^{* *} p<0.01,{ }^{* * *} p<0.001$ 
Table $5 b$ lists a number of changes in our estimation methodology for our base specification. We report results using ordinary least squares estimation (Column 1), White's heteroscedasticity robust standard errors instead of clustering (Column 2), conventional standard errors instead of clustering (Column 3), clustering by income groups instead of individual countries (column 4), and by trimming the observations at the $99 \%$ level instead of winsorizing.

Our baseline results are robust to all of these perturbations. In particular, our interactive term continues to enter negatively with similar point estimates to those in our baseline specification at statistically significant levels.

\section{5c. Dropping outliers}

To ensure that our results are not driven by outliers, we examine our base specification results for samples with outlier values for a variety of variables omitted, with outliers identified as values lying three standard deviations above or below our sample means as indicated.

Our results are shown in Table 5c. We drop banks with exceptionally high lending growth (Column 1), very low lending growth (Column 2), exceptionally high shares of problem loans (Column 3), exceptionally high cash holdings (Column 4), and those with very high equity holdings (Column 5). In all cases, our results are qualitatively similar to those we obtain with our base specification and sample. In particular, the interactive term of interest, $S P N D_{j} x D E B T_{j}$ enters significantly negatively throughout with similar point estimates to those in our base regression. ${ }^{16}$

\footnotetext{
${ }^{16}$ As discussed above, we found that Japanese banks were influential due to the large debt/GDP levels prevailing in Japan. We therefore check the influence that Japanese banks have on our results (Appendix Table A6). Overall, the results are similar to our base sample, with the primary difference being the reduced coefficient estimate and statistical insignificance of the interaction between public debt and COVID-19 fiscal spending (SPNDj XDEBTj). Most
} 
Table 5c. Robustness checks: outlier banks dropped.

\begin{tabular}{|c|c|c|c|c|c|}
\hline & $\begin{array}{c}(1) \\
\text { HI-GLOAN }\end{array}$ & $\begin{array}{c}(2) \\
\text { LO-GLOAN }\end{array}$ & $\begin{array}{c}(3) \\
\text { HI-BADL } \\
\end{array}$ & $\begin{array}{c}\text { (4) } \\
\text { HI-CASH } \\
\end{array}$ & $\begin{array}{c}(5) \\
\text { HI-EQUI }\end{array}$ \\
\hline \multirow[t]{2}{*}{ SPND } & 0.6 & 0.8 & 0.8 & 0.7 & 0.7 \\
\hline & $(0.5)$ & $(0.5)$ & (0.5) & $(0.5)$ & $(0.5)$ \\
\hline \multirow[t]{2}{*}{ SPNDxDEBT } & $-1.6^{*}$ & $-1.9^{* *}$ & $-2.2^{* *}$ & $-2.0^{* *}$ & $-1.9^{*}$ \\
\hline & (0.7) & $(0.7)$ & $(0.8)$ & (0.7) & $(0.8)$ \\
\hline \multirow[t]{2}{*}{ DEBT } & $22.9^{*}$ & $27.2^{*}$ & $31.4^{*}$ & $27.8^{*}$ & $27.5^{*}$ \\
\hline & (10.9) & (11.0) & (12.5) & (11.0) & (11.9) \\
\hline \multirow[t]{2}{*}{ CV19 } & -0.8 & -0.9 & $-1.2^{*}$ & -0.9 & -1.0 \\
\hline & (0.5) & (0.5) & (0.6) & (0.5) & (0.5) \\
\hline \multirow[t]{2}{*}{ GGDP } & 0.3 & 0.4 & 0.4 & 0.4 & 0.4 \\
\hline & (0.3) & $(0.3)$ & $(0.3)$ & $(0.3)$ & $(0.3)$ \\
\hline \multirow[t]{2}{*}{ POPN } & 0.5 & 0.3 & 0.3 & 0.4 & 0.4 \\
\hline & $(0.2)$ & $(0.2)$ & $(0.3)$ & $(0.2)$ & (0.3) \\
\hline \multirow[t]{2}{*}{ HIC } & $11.7^{* * *}$ & $12.0^{* * *}$ & $12.6^{* * *}$ & $12.8^{* * *}$ & $12.7^{* * *}$ \\
\hline & (1.5) & (1.7) & (1.7) & (1.6) & (1.7) \\
\hline \multirow[t]{2}{*}{ UMC } & 1.4 & 2.5 & 2.3 & 2.6 & 2.6 \\
\hline & $(2.2)$ & (2.2) & (2.5) & (2.4) & (2.4) \\
\hline \multirow[t]{2}{*}{ LGLOAN } & $0.2^{* * *}$ & $0.3^{* * *}$ & $0.3^{* * *}$ & $0.2^{* * *}$ & $0.3^{* * *}$ \\
\hline & $(0.0)$ & $(0.0)$ & $(0.0)$ & $(0.0)$ & $(0.0)$ \\
\hline \multirow[t]{2}{*}{ BADL } & $-19.1^{* *}$ & $-17.7^{* *}$ & $-28.5^{* *}$ & $-20.4^{* *}$ & $-21.7^{* *}$ \\
\hline & (5.8) & (6.1) & (9.4) & (6.3) & (6.6) \\
\hline \multirow[t]{2}{*}{ CASH } & -0.8 & 1.2 & 1.5 & 1.5 & 0.3 \\
\hline & (3.8) & (4.1) & (4.5) & (5.2) & (4.3) \\
\hline \multirow[t]{2}{*}{ EQUI } & $-0.1^{* *}$ & -0.1 & -0.1 & -0.1 & $-0.1^{*}$ \\
\hline & $(0.0)$ & $(0.0)$ & (0.1) & (0.1) & (0.1) \\
\hline \multirow[t]{2}{*}{ DEPO } & $6.2^{* *}$ & $6.1^{* *}$ & $8.1^{* *}$ & $7.4^{* *}$ & $8.0^{* *}$ \\
\hline & (2.3) & $(2.2)$ & (2.7) & (2.5) & (2.8) \\
\hline \multirow[t]{2}{*}{ Constant } & -13.5 & $-15.9^{*}$ & $-18.5^{*}$ & $-17.3^{*}$ & $\begin{array}{l}-17.0^{*} \\
\end{array}$ \\
\hline & (7.2) & (7.3) & (8.1) & (7.6) & (7.9) \\
\hline$\overline{R^{2}}$ & 0.3 & 0.3 & 0.3 & 0.3 & 0.3 \\
\hline Observations & 3261 & 3259 & 3213 & 3213 & 3218 \\
\hline
\end{tabular}

Note: Standard errors, clustered by country, are in parentheses. HI-GLOAN refers to a sample without banks with lending growth (GLOAN) higher than the 99th percentile; similarly defined for HI-BADL, HI-CASH, and HI-EQUI. LOGLOAN refers to a sample without banks with lending growth lower than the 1st percentile. Each column shows the estimates based on the single-equation instrumental-variables regression. The endogenous variables are COVID-19 fiscal spending and its interaction with public debt/GDP; SPND and SPNDxDEBT, and the instruments are political-economy variables; POLR, GVEF, PRES, and DURA; using the 2SLS estimator.

${ }^{*} p<0.05,{ }^{* *} p<0.01,{ }^{* * *} p<0.001$

of the other variables enter with similar signs and comparable significance levels, including the weighted least squares specification in which the interactive term enters significantly again with its predicted negative sign. 
The crisis itself only exacerbated fiscal challenges faced by countries, as governments felt compelled to extend sizable transfers to adversely affected households and businesses. This may portend continued difficulties after the global pandemic subsides, as nations' expanded fiscal burden may continue to constrain lending growth going forward.

In turn, as governments normalize policy in the wake of recovery from the pandemic, tightened financial conditions may amplify lending crunches and increase sharply the flow costs of serving debt overhangs in exposed countries. ${ }^{17}$

\section{Conclusion}

This study investigates the implications of government debt positions in the efficacy of fiscal expansion under the COVID-19 pandemic in encouraging commercial bank lending growth. We address the likely endogeneity of government assistance under the pandemic by instrumenting for extra-normal spending using disparities in pre-existing national political characteristics for identification.

Our results indicate that higher public debt going into the crisis weakened the expansionary effects of higher spending on bank lending at economically and statistically significant levels. This suggests that the fiscal multiplier for credit extension, as represented by bank lending growth, was larger for countries that entered the pandemic in superior fiscal positions. Moreover, this sensitivity was higher among weaker banks, suggesting that bank lending responses to government spending under

\footnotetext{
${ }^{17}$ The Economist (February, 2022) projects increased interest rates faced by firms, households and governments by a percentage point over the next three years. Under the assumption that this increase feeds through in five years to government and household debt, and over two years to company borrowing, and that nominal incomes rise in line with the IMF's forecasts while debt-to-GDP ratios stay flat, they project that the interest bill will reach $15 \%$ of projected GDP in 2026. If rates were to rise twice as quickly, say because inflation of more rapid tightening in response to inflation pressures, the interest bill could rise to about a fifth of GDP.
} 
COVID-19 reflected the perceived implications of such spending for government assistance of the banking sector going forward.

\section{References}

Acharya, V., Drechsler, I., \& Schnabl, P. (2014). A pyrrhic victory? Bank bailouts and sovereign credit risk. The Journal of Finance, 69(6), 2689-2739.

Anderson, J., F. Papadia and N. Véron (2021) 'COVID-19 credit-support programmes in Europe's five largest economies, Working Paper 03/2021, Bruegelfive largest economies, Working Paper 03/2021, Bruegel.

Berger, A. N., A. Demirgüç-Kunt, F. Moshirian et al. (2021). The way forward for banks during the COVID 19 crisis and beyond: Government and central bank responses, threats to the global banking industry. Journal of Banking \& Finance, 106303.

Bighelli, T., Lalinsky, T., \& Vanhala, J. (2023). Cross-country evidence on the allocation of COVID-19 government subsidies and consequences for productivity. Journal of the Japanese and International Economies, 101246.

Brandao-Marques, L., R. Correa, and H. Sapriza. (2020). Government support, regulation, and risk taking in the banking sector. Journal of Banking and Finance, 112, 105284, 1-15.

Cetorelli, N., \& Goldberg, L. S. (2012). Banking globalization and monetary transmission. The Journal of Finance, 67(5), 1811-1843. 
Çolak, G., \& Öztekin, Ö. (2021). The Impact of COVID-19 Pandemic on Bank Lending Around the World. Journal of Banking \& Finance, 106207.

Cornett, M. M., McNutt, J. J., Strahan, P. E., \& Tehranian, H. (2011). Liquidity risk management and credit supply in the financial crisis. Journal of financial economics, 101(2), 297-312.

Correa, R., K. H. Lee, H. Sapriza, and G. A. Suarez (2014). Sovereign Credit Risk, Banks' Government Support, and Bank Stock Returns around the World. Journal of Money, Credit and Banking, 46(1), 93-121.

Crosignani, Matteo. (2021). Bank capital, government bond holdings, and sovereign debt capacity. Journal of Financial Economics, 141(2), 693-704.

Cukierman, A., \& Izhakian, Y. (2015). Bailout uncertainty in a microfounded general equilibrium model of the financial system. Journal of Banking \& Finance, 52, 160-179.

Fortunato, D., \& Loftis, M. W. (2018). Cabinet durability and fiscal discipline. American Political Science Review, 112(4), 939-953.

Ghosh, A. R., Kim, J. I., Mendoza, E. G., Ostry, J. D., \& Qureshi, M. S. (2013). Fiscal fatigue, fiscal space and debt sustainability in advanced economies. The Economic Journal, 123(566), F4-F30

Gopinath, G. (2020) “A Long, Uneven and Uncertain Ascent,” IMF Blog, October 13, 2020. https://blogs.imf.org/2020/10/13/a-long-uneven-and-uncertain-ascent/

Honda, T., Hosono, K., Miyakawa, D., Ono, A., \& Uesugi, I. (2023). Determinants and effects of the use of COVID-19 business support programs in Japan. Journal of the Japanese and International Economies, 67, 101239.

Heylen, F., Hoebeeck, A., \& Buyse, T. (2013). Government efficiency, institutions, and the effects of fiscal consolidation on public debt. European journal of political economy, 31, 40-59. 
Lopez, J. A., Rose, A. K., \& Spiegel, M. M. (2020). Why have negative nominal interest rates had such a small effect on bank performance? Cross country evidence. European Economic Review, 124, 103402.

Lopez, J. A., \& Spiegel, M. M. (2021, April). Small business lending under the PPP and PPPLF programs. Federal Reserve Bank of San Francisco Working Paper no. 2021-10.

Mian, A., Sufi, A., \& Trebbi, F. (2014). Resolving debt overhang: Political constraints in the aftermath of financial crises. American Economic Journal: Macroeconomics, 6(2), 1-28.

Ostry, J. D., Ghosh, A. R., Kim, J. I., \& Qureshi, M. S. (2010). Fiscal space. IMF Staff Position Notes, 2010 (011).

Spiegel, M. M. (2022), “Monetary Policy Spillovers Under COVID-19: Evidence from Lending by U.S. Foreign Bank Subsidiaries," forthcoming, Journal of International Money and Finance.

The Economist (2022), "The bill balloons, The global interest bill is about to jump," February. 
Appendix

Table A1. Data sources and descriptions

\begin{tabular}{|c|c|c|}
\hline Data & Description & Date Accessed \\
\hline $\begin{array}{l}\text { Bank Lending Growth; lagged } \\
\text { term } \\
\text { (GLOAN; LGLOAN) } \\
\text { Bank-Level Controls } \\
\text { (BADL: Bad Loans Ratios; } \\
\text { CASH: Cash to Total Assets; } \\
\text { EQUI: Equity to Total Assets; } \\
\text { DEPO: Deposit to Total } \\
\text { Assets; LEVR: Leverage } \\
\text { Ratios; CAPR: Capital Ratios; } \\
\text { SIZE: Total Assets) }\end{array}$ & $\begin{array}{l}\text { Bank-level data are from } \\
\text { FitchSolutions. US banks are } \\
\text { not in the sample. The } \\
\text { variables are drawn from the } \\
\text { quarterly reports. Stock } \\
\text { measures from 2019Q4, } \\
\text { while growth measure from } \\
\text { 2018Q4-2019Q4. }\end{array}$ & 2021-11-11 \\
\hline $\begin{array}{l}\text { COVID-19 above-the-line } \\
\text { fiscal spending } \\
\text { (SPND: COVID-19 Fiscal } \\
\text { Spending; LIQS: COVID-19 } \\
\text { Liquidity Supports) }\end{array}$ & $\begin{array}{l}\text { Data on pandemic policy } \\
\text { supports are from Fiscal } \\
\text { Monitor Database of Country } \\
\underline{\text { Fiscal Measures in Response }} \\
\underline{\text { to the COVID-19 Pandemic. }}\end{array}$ & 2021-11-16 \\
\hline $\begin{array}{l}\text { Public Debt and Macro } \\
\text { Controls } \\
\text { (DEBT: Public Debt/GDP; } \\
\text { GGDP: GDP Growth; POPN: } \\
\text { Population) }\end{array}$ & $\begin{array}{l}\text { Macroeconomic pre- } \\
\text { conditions are drawn from } \\
\text { national authorities and } \\
\text { international organizations } \\
\text { via Thomson Reuters Eikon. }\end{array}$ & $2021-12-11$ \\
\hline $\begin{array}{l}\text { COVID-19 Excess Deaths } \\
\text { (CV19) }\end{array}$ & $\begin{array}{l}\text { COVID-19 estimates of excess } \\
\text { deaths (per million } \\
\text { population) are from the } \\
\text { Economist's Global Excess } \\
\text { Deaths model. }\end{array}$ & $2021-09-12$ \\
\hline $\begin{array}{l}\text { Institutional Variables } \\
\text { (POLR: Political Rights; DURA: } \\
\text { Regime Durability; GVEF: } \\
\text { Government Effectiveness; } \\
\text { PRES: Presidential System) }\end{array}$ & $\begin{array}{l}\text { Government Effectiveness } \\
\text { (PRS19GE): an index from } \\
\text { International Country Risk } \\
\text { Guide (2019). The index goes } \\
\text { from } 0 \text { to 1; higher value }\end{array}$ & $2020-12-14$ \\
\hline
\end{tabular}




\begin{tabular}{|c|c|c|}
\hline & $\begin{array}{l}\text { corresponds to higher } \\
\text { government effectiveness. } \\
\text { Regime Durability: number of } \\
\text { years since the most recent } \\
\text { regime change as of 2018, } \\
\text { from the Quality of } \\
\text { Government Basic Dataset. } \\
\text { Political Rights: an index from } \\
\text { Freedom House; re-scaled to } \\
\text { (0,1), the higher value the } \\
\text { higher degree of political } \\
\text { freedom. } \\
\text { Presidential System: } 1 \text { if } \\
\text { presidential system and } 0 \\
\text { otherwise, from the } \\
\text { Database of Political } \\
\text { Institutions. }\end{array}$ & \\
\hline Country Classification & $\begin{array}{l}\text { The latest classification of } \\
\text { income and geographic } \\
\text { regions is from World Bank, } \\
\text { and also IMF's classification } \\
\text { to identify emerging market } \\
\text { and middle-income } \\
\text { economies not classified as } \\
\text { advanced economies or low- } \\
\text { income developing countries, } \\
\text { together with the list of Euro } \\
\text { membership. The bank-level } \\
\text { and country-level } \\
\text { observations are combined } \\
\text { using 2-digit (Eikon) and 3- } \\
\text { digit (FitchSolutions) country } \\
\text { letter codes in the respective } \\
\text { datasets. }\end{array}$ & 2022-01-17 \\
\hline
\end{tabular}


Table A2. Countries, Bank Lending Growth, and Numbers of Banks.

\begin{tabular}{|c|c|c|c|}
\hline & Mean & Standard deviation & Frequency \\
\hline \multicolumn{4}{|l|}{ Country Name } \\
\hline ANGOLA & -.3936534 & 9.290697 & 4 \\
\hline ARGENTINA & -10.46485 & 8.049706 & 11 \\
\hline ARMENIA & 2.772249 & 5.752794 & 14 \\
\hline AUSTRALIA & 7.378775 & 14.93947 & 7 \\
\hline AUSTRIA & 7.697911 & 2.332107 & 15 \\
\hline AZERBAIJAN & -3.137809 & 8.971643 & 12 \\
\hline BANGLADESH & 4.08094 & 5.477196 & 44 \\
\hline BELARUS & -2.773004 & 8.576385 & 20 \\
\hline BELGIUM & 4.890028 & 5.481459 & 12 \\
\hline BRAZIL & -2.49153 & 11.25935 & 91 \\
\hline CANADA & 4.201277 & 6.888722 & 52 \\
\hline CHILE & .2429554 & 7.08765 & 14 \\
\hline CHINA & 11.09144 & 5.459312 & 136 \\
\hline COLOMBIA & 1.198453 & 8.366584 & 34 \\
\hline CZECH REPUBLIC & 7.406158 & 10.29503 & 18 \\
\hline DENMARK & 3.320947 & 3.083934 & 25 \\
\hline DOMINICAN REPUBLIC & -1.06215 & 9.969654 & 35 \\
\hline EGYPT & 6.24083 & 4.759595 & 21 \\
\hline ESTONIA & 15.76603 & 12.46978 & 8 \\
\hline FINLAND & 8.758173 & 6.221393 & 10 \\
\hline FRANCE & 11.83452 & 7.62264 & 134 \\
\hline GERMANY & 9.006659 & 3.583502 & 735 \\
\hline GHANA & 2.362549 & 9.980984 & 15 \\
\hline GREECE & 5.133044 & 6.728921 & 6 \\
\hline HUNGARY & 6.389607 & .7639742 & 8 \\
\hline INDONESIA & -1.872382 & 9.364711 & 89 \\
\hline IRELAND & 2.331326 & 3.760049 & 11 \\
\hline ISRAEL & 8.997868 & 5.781368 & 8 \\
\hline ITALY & 8.267946 & 6.282174 & 211 \\
\hline JAPAN & 2.697825 & 3.487492 & 398 \\
\hline JORDAN & 3.350864 & 5.229394 & 12 \\
\hline KAZAKHSTAN & -4.153718 & 9.633135 & 14 \\
\hline KENYA & .4341425 & 5.989796 & 34 \\
\hline KOREA (SOUTH), REPUBLIC OF & 13.97867 & 9.13609 & 96 \\
\hline KUWAIT & -.1757287 & 2.571886 & 5 \\
\hline LATVIA & 3.388634 & 5.852212 & 7 \\
\hline LITHUANIA & 4.736902 & 3.726434 & 4 \\
\hline LUXEMBOURG & 7.170396 & 4.715736 & 3 \\
\hline MALAYSIA & -.1142207 & 6.758919 & 22 \\
\hline MEXICO & -4.224548 & 8.191903 & 61 \\
\hline MOLDOVA, REPUBLIC OF & 4.716295 & 8.419125 & 9 \\
\hline MOROCCO & 8.266481 & 8.725383 & 9 \\
\hline MOZAMBIQUE & -3.716218 & 7.548597 & 9 \\
\hline NETHERLANDS & 4.37421 & 5.64296 & 10 \\
\hline
\end{tabular}




\begin{tabular}{l|rrr} 
NEW ZEALAND & 9.636285 & 8.95596 & 5 \\
NIGERIA & -1.172624 & 8.541499 & 19 \\
NORWAY & 4.137159 & 6.66876 & 37 \\
PAKISTAN & .102639 & 10.34309 & 29 \\
PERU & -.8236039 & 10.5718 & 14 \\
PHILIPPINES & -.3245118 & 6.867227 & 31 \\
POLAND & .4941578 & 5.816453 & 13 \\
PORTUGAL & 5.51794 & 5.419299 & 14 \\
ROMANIA & 10.7938 & 6.120651 & 18 \\
RUSSIAN FEDERATION & -7.380609 & 7.145761 & 46 \\
SAUDI ARABIA & 3.586703 & 5.691111 & 7 \\
SINGAPORE & 1.345438 & 4.80082 & 8 \\
SLOVAKIA & 8.263117 & 6.847744 & 10 \\
SLOVENIA & 9.103508 & 9.515633 & 12 \\
SOUTH AFRICA & -.6559664 & 2.878194 & 10 \\
SPAIN & 7.849073 & 5.21747 & 42 \\
SRI LANKA & 2.31878 & 7.28286 & 17 \\
SWEDEN & 14.00908 & 6.072209 & 70 \\
SWITZERLAND & 10.90178 & 3.659598 & 196 \\
THAILAND & 2.539306 & 8.159744 & 21 \\
TURKEY & -1.497363 & 7.991708 & 24 \\
UGANDA & 4.161587 & 7.54581 & 9 \\
UKRAINE & -5.425294 & 11.44177 & 27 \\
UNITED ARAB EMIRATES & -2.249336 & 8.378167 & 21 \\
UNITED KINGDOM & 3.963256 & 5.692852 & 75 \\
VIETNAM & 8.937131 & 6.009928 & 22 \\
ZAMBIA & -5.897465 & 4.43368 & 8.114546 \\
TOtal & 5.691272 & & 21 \\
\hline
\end{tabular}


Table A3. Detailed Summary Statistics.

\begin{tabular}{|c|c|c|c|c|c|}
\hline \multicolumn{3}{|c|}{ Whole Sample } & \multicolumn{3}{|c|}{ High-income Economies } \\
\hline & Mean & SD & & Mean & SD \\
\hline GLOAN & 5.691 & 8.115 & GLOAN & 7.69 & 6.341 \\
\hline LGLOAN & 3.72 & 7.003 & LGLOAN & 2.588 & 5.672 \\
\hline BADL & .043 & .056 & BADL & .034 & .045 \\
\hline $\mathrm{CASH}$ & .082 & .099 & $\mathrm{CASH}$ & .066 & .09 \\
\hline EQUI & 10.504 & 6.136 & EQUI & 8.928 & 4.305 \\
\hline DEPO & .817 & .183 & DEPO & .836 & .167 \\
\hline LEVR & 11.524 & 7.168 & LEVR & 12.947 & 7.437 \\
\hline SPND & 10.238 & 5.408 & SPND & 12.627 & 4.306 \\
\hline SPNDxDEBT & 10.284 & 11.686 & SPNDXDEBT & 13.655 & 12.465 \\
\hline DEBT & .836 & .627 & DEBT & .969 & .694 \\
\hline LIQS & 15.024 & 12.463 & LIQS & 20.578 & 10.803 \\
\hline CV19 & 1.088 & 1.01 & CV19 & .958 & .896 \\
\hline GGDP & -4.273 & 3.15 & GGDP & -4.987 & 2.419 \\
\hline POPN & 1.348 & 2.758 & POPN & .663 & .395 \\
\hline POLR & 5.905 & 1.894 & POLR & 6.85 & .738 \\
\hline DURA & 53.048 & 41.279 & DURA & 63.689 & 43.168 \\
\hline GVEF & .8 & .226 & GVEF & .919 & .138 \\
\hline PRES & .283 & .451 & PRES & .147 & .354 \\
\hline
\end{tabular}

\begin{tabular}{|c|c|c|c|c|c|}
\hline \multicolumn{3}{|c|}{ Upper-middle-income Economies } & \multicolumn{3}{|c|}{ Lower-middle and Low-income Economies } \\
\hline & Mean & SD & & Mean & SD \\
\hline GLOAN & 1.077 & 10.435 & GLOAN & .977 & 8.698 \\
\hline LGLOAN & 6.436 & 9.02 & LGLOAN & 6.252 & 8.648 \\
\hline BADL & .056 & .066 & BADL & .074 & .078 \\
\hline $\mathrm{CASH}$ & .11 & .1 & $\mathrm{CASH}$ & .131 & .115 \\
\hline EQUI & 14.016 & 8.046 & EQUI & 14.399 & 7.781 \\
\hline DEPO & .72 & .23 & DEPO & .847 & .151 \\
\hline LEVR & 8.34 & 5.152 & LEVR & 8.034 & 5.161 \\
\hline SPND & 5.25 & 3.162 & SPND & 3.888 & 2.956 \\
\hline SPNDxDEBT & 2.996 & 2.569 & SPNDxDEBT & 1.664 & .911 \\
\hline DEBT & .529 & .213 & DEBT & .519 & .229 \\
\hline LIQS & 3.212 & 2.628 & LIQS & .553 & .695 \\
\hline CV19 & 1.647 & 1.309 & CV19 & 1.049 & .87 \\
\hline GGDP & -3.287 & 4.015 & GGDP & -1.692 & 3.625 \\
\hline POPN & 4.172 & 5.738 & POPN & 1.287 & .955 \\
\hline POLR & 3.417 & 2.169 & POLR & 4.09 & 1.477 \\
\hline DURA & 35.228 & 22.461 & DURA & 18.822 & 15.215 \\
\hline GVEF & .524 & .13 & GVEF & .525 & .139 \\
\hline PRES & .594 & .492 & PRES & .61 & .488 \\
\hline
\end{tabular}




\begin{tabular}{|c|c|c|c|c|c|}
\hline \multicolumn{3}{|c|}{ Banks with total assets larger than $\$ 100 B$} & \multicolumn{3}{|c|}{ Banks with total assets lower than $\$ 100 \mathrm{~B}$} \\
\hline & Mean & $\overline{S D}$ & & Mean & $\overline{S D}$ \\
\hline GLOAN & 4.699 & 5.471 & GLOAN & 5.743 & 8.225 \\
\hline LGLOAN & 3.21 & 4.426 & LGLOAN & 3.746 & 7.111 \\
\hline BADL & .026 & .025 & BADL & .044 & .057 \\
\hline CASH & .11 & .095 & CASH & .08 & .099 \\
\hline EQUI & 6.895 & 2.315 & EQUI & 10.691 & 6.214 \\
\hline DEPO & .673 & .182 & DEPO & .825 & .18 \\
\hline LEVR & 15.134 & 5.516 & LEVR & 11.338 & 7.195 \\
\hline SPND & 10.393 & 5.392 & SPND & 10.23 & 5.41 \\
\hline SPNDXDEBT & 11.566 & 12.01 & SPNDXDEBT & 10.218 & 11.667 \\
\hline DEBT & .917 & .613 & DEBT & .832 & .627 \\
\hline LIQS & 11.069 & 10.016 & LIQS & 15.229 & 12.544 \\
\hline CV19 & .966 & 1.006 & CV19 & 1.095 & 1.01 \\
\hline GGDP & -4.166 & 4.134 & GGDP & -4.279 & 3.091 \\
\hline POPN & 2.84 & 5.066 & POPN & 1.271 & 2.561 \\
\hline POLR & 5.444 & 2.401 & POLR & 5.929 & 1.861 \\
\hline DURA & 72.556 & 39.307 & DURA & 52.04 & 41.133 \\
\hline GVEF & .81 & .205 & GVEF & .8 & .228 \\
\hline PRES & .191 & .395 & PRES & .288 & .453 \\
\hline
\end{tabular}

\begin{tabular}{|c|c|c|c|c|c|}
\hline \multicolumn{3}{|c|}{ Banks with deposits/total funding more than 0.75} & \multicolumn{3}{|c|}{ Banks with deposits/total funding less than 0.75} \\
\hline & Mean & SD & & Mean & SD \\
\hline GLOAN & 6.007 & 7.61 & GLOAN & 4.761 & 9.389 \\
\hline LGLOAN & 3.638 & 6.871 & LGLOAN & 3.961 & 7.379 \\
\hline BADL & .041 & .054 & BADL & .049 & .061 \\
\hline CASH & .084 & 101 & CASH & .074 & .092 \\
\hline EQUI & 10.348 & 5.849 & EQUI & 10.966 & 6.894 \\
\hline DEPO & .901 & .074 & DEPO & .571 & .186 \\
\hline LEVR & 11.632 & 7.291 & LEVR & 11.209 & 6.788 \\
\hline SPND & 10.804 & 5.487 & SPND & 8.572 & 4.799 \\
\hline SPNDXDEBT & 11.321 & 12.76 & SPNDXDEBT & 7.231 & 6.845 \\
\hline DEBT & .867 & .682 & DEBT & .744 & .409 \\
\hline LIQS & 16.068 & 12.387 & LIQS & 11.952 & 12.181 \\
\hline CV19 & .955 & .949 & CV19 & 1.481 & 1.08 \\
\hline GGDP & -4.088 & 2.873 & GGDP & -4.819 & 3.801 \\
\hline POPN & 1.14 & 2.183 & POPN & 1.963 & 3.934 \\
\hline POLR & 6.024 & 1.783 & POLR & 5.555 & 2.15 \\
\hline DURA & 51.276 & 41.127 & DURA & 58.264 & 41.309 \\
\hline GVEF & .83 & .223 & GVEF & .714 & .213 \\
\hline PRES & .273 & .445 & PRES & .315 & .465 \\
\hline
\end{tabular}


Table A4. First-stage estimation, drawn from a base specification of Table 2, column 1.

\begin{tabular}{|c|c|c|c|c|}
\hline & $\begin{array}{c}\text { (1) } \\
\text { GLOAN }\end{array}$ & $\begin{array}{c}(2) \\
\text { SPND }\end{array}$ & $\begin{array}{c}(3) \\
\text { SPNDxDEBT }\end{array}$ & $\begin{array}{c}\text { (4) } \\
\text { GLOAN }\end{array}$ \\
\hline \multirow[t]{2}{*}{ SPND } & 0.7 & & & \\
\hline & $(0.5)$ & & & \\
\hline \multirow[t]{2}{*}{ SPNDxDEBT } & $-1.9^{* *}$ & & & \\
\hline & $(0.7)$ & & & \\
\hline \multirow[t]{2}{*}{ LGLOAN } & $0.3^{* * *}$ & $0.0^{* *}$ & $0.1^{* * *}$ & $0.2^{* * *}$ \\
\hline & $(0.0)$ & $(0.0)$ & $(0.0)$ & $(0.0)$ \\
\hline \multirow[t]{2}{*}{ BADL } & $-20.6^{* * *}$ & -0.6 & -2.6 & $-16.2^{* *}$ \\
\hline & $(6.2)$ & $(4.0)$ & (2.9) & $(6.2)$ \\
\hline \multirow[t]{2}{*}{$\mathrm{CASH}$} & 0.8 & 0.0 & $4.0^{*}$ & $-6.8^{* *}$ \\
\hline & (4.0) & $(2.2)$ & (1.7) & $(2.6)$ \\
\hline \multirow[t]{2}{*}{ EQUI } & -0.1 & -0.0 & 0.0 & -0.1 \\
\hline & $(0.0)$ & $(0.0)$ & $(0.0)$ & $(0.0)$ \\
\hline \multirow[t]{2}{*}{ DEPO } & $7.3^{* *}$ & 0.4 & $2.2^{* *}$ & 3.8 \\
\hline & $(2.4)$ & $(1.2)$ & $(0.8)$ & $(2.0)$ \\
\hline \multirow[t]{2}{*}{ GGDP } & 0.4 & -0.4 & -0.0 & 0.2 \\
\hline & $(0.3)$ & $(0.2)$ & $(0.1)$ & $(0.2)$ \\
\hline \multirow[t]{2}{*}{ CV19 } & -1.0 & -0.4 & -0.4 & -0.7 \\
\hline & $(0.5)$ & $(0.6)$ & $(0.4)$ & $(0.5)$ \\
\hline \multirow[t]{2}{*}{ POPN } & 0.4 & 0.3 & -0.1 & $0.6^{* *}$ \\
\hline & $(0.2)$ & $(0.2)$ & $(0.2)$ & $(0.2)$ \\
\hline \multirow[t]{2}{*}{ DEBT } & $27.5^{*}$ & $1.7^{* *}$ & $16.6^{* * *}$ & $-3.7^{* * *}$ \\
\hline & $(11.2)$ & $(0.7)$ & $(0.6)$ & $(0.7)$ \\
\hline \multirow[t]{2}{*}{$\mathrm{HIC}$} & $12.6^{* * *}$ & 0.6 & 0.2 & $11.6^{* * *}$ \\
\hline & $(1.6)$ & (1.9) & $(1.7)$ & $(2.5)$ \\
\hline \multirow[t]{2}{*}{ UMC } & 2.1 & 0.8 & 2.0 & -0.6 \\
\hline & (2.3) & (1.6) & $(1.6)$ & $(1.8)$ \\
\hline \multirow[t]{2}{*}{ POLR } & & 0.4 & -0.2 & 0.7 \\
\hline & & $(0.3)$ & $(0.3)$ & $(0.5)$ \\
\hline \multirow[t]{2}{*}{ GVEF } & & $13.5^{* * *}$ & $11.5^{* * *}$ & $-14.3^{* * *}$ \\
\hline & & $(3.4)$ & $(2.4)$ & $(3.6)$ \\
\hline \multirow[t]{2}{*}{ PRES } & & -1.8 & -1.1 & -0.9 \\
\hline & & $(1.2)$ & (0.9) & $(1.4)$ \\
\hline \multirow[t]{2}{*}{ DURA } & & -0.0 & -0.0 & 0.0 \\
\hline & & $(0.0)$ & $(0.0)$ & $(0.0)$ \\
\hline \multirow[t]{2}{*}{ Constant } & $-16.7^{*}$ & -5.4 & $-13.7^{* * *}$ & $7.4^{*}$ \\
\hline & $(7.5)$ & (3.1) & $(2.3)$ & $(3.5)$ \\
\hline Observations & 3297 & 3297 & 3297 & 3297 \\
\hline F-statistics & 25.3 & 7.14 & 8.80 & 28.57 \\
\hline Underidentification & 7.0 & & & \\
\hline Weak identification & 3.3 & & & \\
\hline
\end{tabular}


Table A5. Bank and country conditioning variables dropped one at a time.

\begin{tabular}{|c|c|c|c|c|c|c|c|c|}
\hline & (1) & $(2)$ & (3) & (4) & (5) & (6) & (7) & (8) \\
\hline \multirow[t]{2}{*}{ SPND } & 0.7 & 0.5 & 0.7 & 0.7 & 0.7 & 1.1 & 0.4 & 0.9 \\
\hline & $(0.5)$ & $(0.4)$ & $(0.4)$ & $(0.5)$ & $(0.5)$ & $(0.6)$ & $(0.3)$ & $(0.4)$ \\
\hline \multirow[t]{2}{*}{ SPNDxDEBT } & $-1.8^{*}$ & $-1.6^{*}$ & $-1.9^{* *}$ & $-1.9^{*}$ & $-1.9^{*}$ & $-2.6^{* *}$ & $-1.5^{* *}$ & $-1.9^{* *}$ \\
\hline & $(0.7)$ & $(0.7)$ & $(0.7)$ & $(0.7)$ & $(0.8)$ & $(0.8)$ & $(0.5)$ & $(0.7)$ \\
\hline \multirow[t]{2}{*}{ DEBT } & $24.1^{*}$ & $23.0^{*}$ & $27.6^{*}$ & $26.6^{*}$ & $27.6^{*}$ & $37.6^{* *}$ & $20.9^{* *}$ & $27.8^{*}$ \\
\hline & $(11.4)$ & (10.6) & (11.2) & (11.5) & (12.0) & (12.9) & (7.9) & (11.4) \\
\hline \multirow[t]{2}{*}{ CV19 } & $-1.1^{*}$ & -0.9 & -1.0 & -0.9 & -1.1 & -1.1 & $-1.3^{*}$ & \\
\hline & $(0.5)$ & $(0.5)$ & $(0.5)$ & $(0.5)$ & $(0.6)$ & $(0.7)$ & $(0.5)$ & \\
\hline \multirow[t]{2}{*}{ GGDP } & 0.4 & 0.3 & 0.4 & 0.4 & 0.5 & $0.7^{*}$ & & $0.6^{*}$ \\
\hline & $(0.3)$ & $(0.3)$ & $(0.3)$ & $(0.3)$ & $(0.3)$ & $(0.3)$ & & $(0.3)$ \\
\hline \multirow[t]{2}{*}{ POPN } & 0.5 & 0.4 & 0.4 & 0.4 & 0.3 & & $0.6^{* * *}$ & 0.4 \\
\hline & $(0.2)$ & $(0.2)$ & $(0.2)$ & $(0.2)$ & $(0.3)$ & & $(0.1)$ & $(0.2)$ \\
\hline \multirow[t]{2}{*}{$\mathrm{HIC}$} & $12.6^{* * *}$ & $11.6^{* * *}$ & $12.6^{* * *}$ & $12.9^{* * *}$ & $12.4^{* * *}$ & $12.7^{* * *}$ & $11.8^{* * *}$ & $11.9^{* * *}$ \\
\hline & $(1.6)$ & $(1.5)$ & $(1.6)$ & $(1.6)$ & $(1.8)$ & $(2.0)$ & $(1.8)$ & (1.9) \\
\hline \multirow[t]{2}{*}{ UMC } & 2.0 & 1.6 & 2.1 & 1.9 & 1.6 & 4.0 & 1.0 & 1.6 \\
\hline & $(2.3)$ & $(2.2)$ & $(2.4)$ & (2.3) & $(2.6)$ & $(2.1)$ & $(1.8)$ & $(2.4)$ \\
\hline \multirow[t]{2}{*}{ LGLOAN } & $0.3^{* * *}$ & & $0.3^{* * *}$ & $0.3^{* * *}$ & $0.3^{* * *}$ & $0.3^{* * *}$ & $0.2^{* * *}$ & $0.2^{* * *}$ \\
\hline & $(0.0)$ & & $(0.0)$ & $(0.0)$ & $(0.0)$ & $(0.0)$ & $(0.0)$ & $(0.0)$ \\
\hline \multirow[t]{2}{*}{ CASH } & 0.1 & -0.8 & & 0.2 & 2.3 & 3.3 & -0.8 & 1.5 \\
\hline & $(4.2)$ & (3.7) & & (4.0) & (4.7) & $(5.0)$ & (3.5) & $(4.2)$ \\
\hline \multirow[t]{2}{*}{ EQUI } & $-0.1^{*}$ & -0.1 & -0.1 & & -0.1 & -0.1 & $-0.1^{*}$ & -0.1 \\
\hline & $(0.1)$ & $(0.0)$ & $(0.0)$ & & $(0.1)$ & $(0.1)$ & $(0.0)$ & $(0.0)$ \\
\hline \multirow[t]{2}{*}{ DEPO } & $6.7^{* *}$ & $6.8^{* *}$ & $7.4^{* *}$ & $7.2^{* *}$ & & $8.4^{* *}$ & $7.1^{* *}$ & $7.5^{* *}$ \\
\hline & $(2.4)$ & $(2.3)$ & $(2.6)$ & $(2.4)$ & & (3.0) & $(2.3)$ & $(2.5)$ \\
\hline \multirow[t]{2}{*}{ BADL } & & $-25.6^{* * *}$ & $-20.6^{* * *}$ & $-21.8^{* * *}$ & $-19.9^{* *}$ & $-23.5^{* * *}$ & $-18.8^{* *}$ & $-22.0^{* * *}$ \\
\hline & & $(6.2)$ & $(6.2)$ & $(6.1)$ & $(6.1)$ & $(6.1)$ & $(5.9)$ & $(5.8)$ \\
\hline \multirow[t]{2}{*}{ Constant } & $-16.0^{*}$ & -11.6 & $-16.7^{*}$ & $-17.4^{*}$ & -10.6 & $-22.5^{*}$ & $-13.0^{*}$ & $-18.6^{*}$ \\
\hline & (7.9) & (6.9) & $(7.2)$ & $(7.7)$ & $(6.6)$ & $(10.0)$ & (5.9) & $(7.6)$ \\
\hline$\overline{R^{2}}$ & 0.3 & 0.3 & 0.3 & 0.3 & 0.3 & 0.2 & 0.3 & 0.3 \\
\hline Observations & 3297 & 3297 & 3297 & 3297 & 3297 & 3297 & 3297 & 3297 \\
\hline \multicolumn{9}{|c|}{$\begin{array}{l}\text { Note: Bank conditioning variables dropped one at a time in columns (1) through (5). Country conditioning variables } \\
\text { dropped in columns (6) through (8). Standard errors, clustered by country, are in parentheses. Each column shows } \\
\text { the estimates based on the single-equation instrumental-variables regression. The endogenous variables are } \\
\text { COVID-19 fiscal spending and its interaction with public debt/GDP; SPND and SPNDxDEBT, and the instruments are } \\
\text { political-economy variables; POLR, GVEF, PRES, and DURA; using the } 2 \text { SLS estimator. } \\
{ }^{*} p<0.05,{ }^{* *} p<0.01,{ }^{* * *} p<0.001\end{array}$} \\
\hline
\end{tabular}


Table A6. Robustness checks: excluding Japanese banks.

\begin{tabular}{|c|c|c|c|c|}
\hline & (1) & (2) & (3) & (4) \\
\hline \multirow[t]{2}{*}{ SPND } & -0.2 & $-0.4^{*}$ & & 0.1 \\
\hline & $(0.6)$ & $(0.2)$ & & $(0.1)$ \\
\hline \multirow[t]{2}{*}{ SPNDxDEBT } & -0.5 & & $-0.8^{*}$ & $-0.8^{* * *}$ \\
\hline & (1.0) & & $(0.3)$ & $(0.1)$ \\
\hline \multirow[t]{2}{*}{ DEBT } & 8.8 & $4.3^{* *}$ & $11.2^{* * *}$ & $11.9^{* * *}$ \\
\hline & (8.7) & (1.5) & (3.2) & (1.3) \\
\hline \multirow[t]{2}{*}{ CV19 } & -1.0 & $-1.1^{*}$ & -0.9 & $-1.0^{* * *}$ \\
\hline & (0.6) & $(0.5)$ & (0.5) & $(0.1)$ \\
\hline \multirow[t]{2}{*}{ GGDP } & 0.2 & 0.2 & 0.2 & 0.1 \\
\hline & $(0.2)$ & $(0.2)$ & (0.2) & (0.0) \\
\hline \multirow[t]{2}{*}{ POPN } & $0.6^{* * *}$ & $0.6^{* * *}$ & $0.6^{* * *}$ & $0.5^{* * *}$ \\
\hline & $(0.1)$ & (0.1) & (0.1) & $(0.0)$ \\
\hline \multirow[t]{2}{*}{ HIC } & $11.6^{* * *}$ & $11.1^{* * *}$ & $11.8^{* * *}$ & $8.7^{* * *}$ \\
\hline & (1.8) & (1.6) & $(1.8)$ & $(0.5)$ \\
\hline \multirow[t]{2}{*}{ UMC } & 0.3 & 0.1 & 0.4 & $1.3^{*}$ \\
\hline & $(1.2)$ & (1.2) & (1.2) & $(0.5)$ \\
\hline \multirow[t]{2}{*}{ LGLOAN } & $0.2^{* * *}$ & $0.2^{* * *}$ & $0.2^{* * *}$ & $0.2^{* * *}$ \\
\hline & $(0.0)$ & (0.0) & (0.0) & $(0.0)$ \\
\hline \multirow{2}{*}{ BADL } & $-19.3^{* *}$ & $-20.9^{* * *}$ & $-18.2^{* *}$ & $-10.9^{* * *}$ \\
\hline & (6.4) & (5.7) & (6.0) & (3.2) \\
\hline \multirow[t]{2}{*}{ CASH } & -3.9 & -4.3 & -3.6 & -0.6 \\
\hline & (3.2) & (2.8) & (2.9) & $(1.3)$ \\
\hline \multirow[t]{2}{*}{ EQUI } & -0.1 & -0.1 & -0.1 & $-0.1^{* *}$ \\
\hline & $(0.0)$ & $(0.0)$ & $(0.0)$ & $(0.0)$ \\
\hline \multirow[t]{2}{*}{ DEPO } & $5.6^{* *}$ & $5.5^{* *}$ & $5.7^{* *}$ & $9.0^{* * *}$ \\
\hline & (1.8) & (1.9) & (1.9) & $(0.5)$ \\
\hline \multirow[t]{2}{*}{ Constant } & -4.6 & -1.7 & $-6.3^{*}$ & $-10.3^{* * *}$ \\
\hline & (6.2) & (2.3) & (2.6) & $(1.3)$ \\
\hline$R^{2}$ & 0.4 & 0.4 & 0.4 & 0.6 \\
\hline Observations & 2899 & 2899 & 2899 & 2899 \\
\hline
\end{tabular}

Note: Standard errors, clustered by country, are in parentheses. Each column shows the estimates based on the single-equation instrumental-variables regression. The endogenous variables are COVID-19 fiscal spending and its interaction with public debt/GDP; SPND and SPNDxDEBT, and the instruments are political-economy variables; POLR, GVEF, PRES, and DURA; using the 2SLS estimator. Column (4) is done with the weighted least squares, with observations weighted by bank total assets. ${ }^{*} p<0.05,{ }^{* *} p<0.01,{ }^{* * *} p<0.001$ 